\title{
Hydrofracturing in response to the development of an overpressurised subglacial meltwater system during drumlin formation; an example from Anglesey, NW Wales
}

\author{
Emrys Phillips ${ }^{* 1}$ and Leanne Hughes ${ }^{2}$ \\ 1. British Geological Survey, Murchison House, West Mains Road, Edinburgh, EH9 3LA, UK \\ 2. British Geological Survey, Keyworth, Nottingham, NG12 5GG, UK \\ * Corresponding author, e-mail: erp@bgs.ac.uk
}

Keywords: hydrofractures, overpressurised meltwater, drumlin formation, micromorphology, Irish Sea Ice Stream

\begin{abstract}
This paper presents the results of a detailed study of a complex hydrofracture system and host diamictons exposed within a longitudinal section through an elongate drumlin located to the west of Cemlyn Bay, Anglesey, NW Wales. This complex, laterally extensive sand, silt and clay filled hydrofracture system was active over a prolonged period and is thought to have developed beneath the Late Devensian (Weichselian) Irish Sea Ice Stream as it overrode this part of NW Anglesey. The sediment-fill to the hydrofracture system is deformed with kinematic indicators (folds, thrusts, augen) recording a SW-directed sense of shear, consistent with the regional ice flow direction across this part of the island. The lack of any geomorphological evidence for active retreat of the Irish Sea ice across Anglesey, has led to the conclusion that hydrofracturing at the Cemlyn Bay site occurred within the bed of the Irish Sea Ice Stream whilst this relatively faster flowing corridor of ice was actively overriding the island. Shear imposed by the overriding ice led to the development of a subglacial shear zone which facilitated the propagation of the hydrofracture system with the laterally extensive feeder sills occurring parallel to Y-type Riedel shears. Although a subglacial setting beneath the active Irish Sea Ice Stream can be argued for the Cemlyn Bay hydrofracture system, its relationship to the formation of the 'host' drumlin remains uncertain. However, evidence presented here suggests that hydrofracturing may have occurred during the later stages or post landform development in response to the migration of overpressurised meltwater within the bed of the Irish Sea ice; possibly accompanying the local thinning and shutdown of the Irish Sea Ice Stream on Anglesey.
\end{abstract}

\section{Introduction}

During the Late Devensian (Weichselian), Anglesey (Fig. 1a) was located close to the eastern margin of the Irish Sea Ice Stream (Thomas and Chiverrell, 2007; Phillips et al., 2010b). This corridor of relatively faster moving ice, sourced in central and southwest Scotland, flowed southwest through the Irish Sea Basin (Merritt and Auton, 2000; Evans and Ó Cofaigh, 2003; Roberts et al., 2007) where it met, coalesced with and ultimately decoupled from ice emanating from several ice caps 
surrounding the Irish Sea, including the Welsh Ice Sheet centred on Snowdonia (McCarroll, 2005; Thomas and Chiverrell, 2007). The Irish Sea Ice Stream is one of a number of ice streams that helped regulate the size and shape of the British and Irish Ice Sheet, and at its maximum extent, reached the Isles of Scilly (Scourse, 1991a and b; Hiemstra et al., 2006; Thomas and Chiverrell, 2007; Phillips et al., 2010b; Clark et al., 2012) (Fig. 1).

The relatively faster flow of ice within ice streams, such as the Irish Sea Ice Stream, is thought to be largely controlled by conditions at the bed of these ice masses (e.g. Clark and Stokes, 2001; Bennett, 2003; Bamber et al., 2003; Benn and Evans, 2010). The introduction of pressurised meltwater into the bed of a glacier or ice sheet is widely regarded as leading to either enhanced sliding of the ice over areas of bedrock (hard bed), or the weakening and enhanced deformation of the unconsolidated sediments (soft bed) which may underlie the ice stream (Benn and Evans, 2010 and references therein). Hydrofractures, also referred to as water-escape features or clastic dykes, provide clear evidence for the movement of pressurised meltwater through subglacial to icemarginal environments (Dionne and Shilts 1974; Christiansen et al., 1982; von Brunn and Talbot, 1986; Burbridge et al., 1988; Dreimanis, 1992; Larsen and Mangerud 1992; McCabe \& Dardis 1994; Dreimanis and Rappol, 1997; van der Meer et al., 1999; Rijsdijk et al., 1999; Le Heron and Etienne 2005; Boulton, 2006; Goździk and van Loon, 2007; van der Meer et al., 2008; Phillips and Merritt, 2008; Phillips et al., 2012a). They record marked changes in hydrostatic pressure within the subglacial hydrogeological system which led to brittle fracturing of the pre-existing sediment and/or bedrock, and penecontemporaneous liquefaction and introduction of a sediment-fill (see van der Meer et al., 2008; Phillips et al., 2013 and references therein). Due to the pressurised nature of the meltwater, the sediment infill can be introduced from structurally above (downward injection) or below (upward injection) the developing hydrofracture system (Dreimanis, 1992; Rijsdijk et al., 1999; Le Heron and Etienne, 2005; Goździk and van Loon 2007; van der Meer et al., 2008). The introduction of pressurised meltwater beneath glaciers and ice sheets can have a profound effect on deformation beneath the ice not only leading to increased forward motion, but also the development of water-lubricated detachments within the sediment pile (e.g. Phillips et al., 2002; Kjær et al., 2006; Benediktsson et al., 2008), or the detachment and transport of sediment and/or bedrock rafts (e.g. Moran et al., 1980; Broster, 1991; Broster and Seaman, 1991; Benn and Evans, 2010; Phillips and Merritt, 2008; Burke et al., 2009; Vaughan-Hirsh et al., 2013).

This paper presents the results of a detailed study of a laterally extensive sediment-filled fracture system, interpreted as a hydrofracture system, cutting the glacigenic sediments exposed in within a drumlin located to the west of Cemlyn Bay in northern Anglesey, NW Wales (Fig. 1). The glacigenic sediments and landforms preserved within this part of NW Anglesey were developed when the island was overridden by the Irish Sea Ice Stream and, therefore, provide valuable insights into the conditions encountered beneath this ice stream. Field sedimentological and structural evidence are combined with micromorphological analysis to demonstrate that hydrofracturing probably occurred during the later stages of drumlin formation in response to the repeated introduction of overpressurised meltwater into the bed of the Irish Sea ice. Kinematic evidence (folds, shears, faults) preserved within deformed sediments filling the hydrofracture is used to demonstrate that fracture propagation was facilitated by shear imposed by the overriding ice. The results of this study are used to place the development of this hydrofracture system within the broader context of the overall evolution of the Irish Sea Ice Stream as it overrode Anglesey. 


\section{Quaternary geology of the study area}

The glacial geomorphology and sedimentary succession preserved on Anglesey has largely been interpreted as providing a record of the processes that occurred beneath the Irish Sea Ice Stream. Thomas and Chiverrell (2007) and Phillips et al. (2010b) divided this sequence into three sedimentlandform assemblage zones (Fig. 1b):

- Zone 1 - an extensive subglacial depositional assemblage covering much of northern and western Anglesey, and dominated by an extensive drumlin field (Greenly, 1919). The drumlins vary from being mainly composed of diamicton, through to bedrock dominated features encased in a relatively thin carapace of this diamicton;

- Zone 2 - a subglacial erosional assemblage of NE-SW-trending ice-moulded bedrock ridges forming an elongate tract across the central part of the island;

- Zone 3 - an undifferentiated subglacial erosional and depositional assemblage of elongate bedrock ridges, solitary drumlinoid landforms, bedrock channels and proglacial outwash (Helm and Roberts, 1984) and subglacial (esker) deposits that cover the remainder of the island.

Geomorphological mapping of part of the offshore area to the north of Anglesey (van Landeghem et al., 2009) has shown that a comparable suite of glacigenic landforms occur beneath this part of the Irish Sea. Phillips et al. (2010b) demonstrated that changes in the morphology, orientation and distribution of the subglacial landforms on Anglesey closely matches the underlying bedrock, concluding that bedrock geology potentially played an important role in controlling the relative velocity of the overriding Irish Sea ice.

The present study focuses on a laterally extensive sediment-filled fracture system cutting a sequence of weakly stratified diamictons exposed in a longitudinal section through an elongate drumlin located immediately to the west of Cemlyn Bay on the NW coast of Anglesey (National Grid Reference SH 327 936) (Fig. 1). The study area occurs well within sediment-landform assemblage zone 1 (Fig. 1b) with the drumlins in this area forming part of the western Anglesey drumlin field first identified by Greenly (1919). The geology of this part of NW Anglesey (Fig. 1c) is dominated by a locally developed layer of diamicton (up to c 10-15 m thick) overlying the highly deformed and metamorphosed bedrock of the Cambrian in age Monian Supergroup (Greenly, 1919; Shackleton, 1975; Phillips, 1989, 1991a, b; Collins and Buchan, 2004; Howells, 2007). Small areas of glacial sands and gravels have been identified within the larger, subglacial meltwater channels which are cut into the bedrock exposed between Hen-dy (SH 304 914) and Carmel Head (SH 298 930), and locally within the lower ground between the drumlins (Fig. 1c). The drumlins range in size and typically form low-lying elongate features with a prominent crest line. They are often single isolated landforms with a long profile of up to a kilometre, but more complex features with marked, undulating crest lines have also been identified (Fig. 1d). The NE-SW-trending long axes of these subglacial landforms and glacial striae identified on glacially smoothed bedrock surfaces in the western part of the study area (Fig. 1c) record an overall SW-directed ice movement across this part of NW Anglesey, consistent with their formation beneath the Irish Sea Ice Stream as it overrode the island. 


\section{Methodology}

The study focuses on a NE-SW-trending cliff section (15-20 m high, $300 \mathrm{~m}$ long) at the Cemlyn Bay site (SH 327 936) is orientated parallel to the principal ice flow direction across the island (Figs. 1c and e). Prior to sampling the sediment-filled fracture system, the glacial sediments exposed within the core of the drumlin were logged and described based on their sedimentological, lithological and structural characteristics using the standard methodologies outlined in Evans and Benn (2004). A sequence of photographs were taken of key parts of the cliff section enabling the detailed analysis of the small- and meso-scale structures developed within the fracture system and host diamictons and underlying schistose metasedimentary bedrock (Figs. 1e, 2, 3 and 4). The orientations of the fracture system, lamination within the sediment-fill and deformation structures (folds, foliations, joints) were measured using a compass clinometer. A total of five intact block samples (E75038 to E75042; Fig. 2) of the sediment-fill and adjacent diamicton were taken using $10 \mathrm{~cm}$ cubed, aluminium Kubiena tins. The tins were gently cut into the face in order to limit sample disturbance. The geographical position, orientation relative to magnetic north, depth and way-up of the sample were marked on the outside of the tin during collection. The samples were collected at different locations along the lowest, and laterally most extensive sediment-filled fracture (Fig. 2) to provide detailed information on its internal architecture and the range of structures developed at various points within this sandand silt-filled feature. A sequence of photographs was then taken of the Kubiena tins embedded in the face to provide a visual record of the location and context of the individual samples within the fracture system. Each sample was then removed from the face, sealed in two plastic bags, and stored in a cold store to prevent the material from drying out prior to sample preparation.

Sample preparation (total time c. 10 months) involved the initial replacement of pore-water by acetone, which was then progressively replaced by a resin and allowed to cure. Large format orientated thin sections were taken from the centre of each of the prepared samples, thus avoiding artefacts associated with sample collection. Each thin section was cut orthogonal to the hydrofracture/vein margin evident from the field investigation. The thin sections were examined using a standard Zeiss petrological microscope and Zeiss projector, the latter allowing detailed study of the range of microstructures at very low magnification. The microstructural mapping technique used to analyses the thin sections is described by Phillips et al., (2010a). The terminology used to describe the various microtextures developed within these sediments in general follows that proposed by van der Meer $(1987,1993,1996)$ and Menzies (2000).

\section{Macro-scale description and interpretation}

The longitudinal section through an elongate drumlin to the west of Cemlyn Bay shows that it is composed of a 10 to $15 \mathrm{~m}$ thick sequence of weakly stratified diamictons which are cut by a number of sediment-filled fractures (Figs. 1e and 2). The sequence of stratified diamictons is underlain by polydeformed metasedimentary (greenschist to sub-greenschist facies) rocks belonging to the New Harbour Group (Greenly, 1919; Maltman, 1977; Phillips, 1989; 1991a, b), which are exposed on the foreshore. The boundary between the bedrock and the glacial sediments was not exposed, but can be located to within $50 \mathrm{~cm}$ of the top of the beach at the northern end of the section. The pale to dark green, chlorite-quartz-schists possess a well-developed schistosity which dips at a low to 
moderate angle towards the N/NW. This bedrock fabric overprints bedding within these metamudstones and metasandstones and is itself deformed by several phases of asymmetrical, SEverging folds and associated axial planar cleavages (Maltman, 1977; Phillips, 1991b).

The glacial sequence can be subdivided into two main units (Fig. 2); a lower bedrock-rich, clast- to matrix-supported, dark blue-grey to green-grey diamicton (1 to $2.5 \mathrm{~m}$ thick) composed of angular to subrounded pebble to occasionally boulder-sized clasts of locally derived schistose metasedimentary rocks derived from the New Harbour Group, overlain by a brown to orange-brown, typically matrix-supported, stratified sandy diamicton. The stratification within this diamicton is highlighted by the presence of cobble- to boulder-sized, clast-rich bands. The upper sandy diamicton comprises a mix of angular locally derived bedrock fragments and more rounded, far travelled clasts including granite, volcanic rocks, Carboniferous limestone and sandstone. This is consistent with this diamicton having been deposited by the Irish Sea ice, the so called Irish Sea Till (see Fig. 2). Both diamictons are hard and compact (overconsolidated) consistent with them having been overridden by ice. A number of the larger clasts within the diamictons are faceted and striated (Fig. 3a) with the striae trending towards $220^{\circ}$, consistent with the SW-directed flow of ice across the area. Phillips et al., (2013) describe a bedrock-rich diamicton directly overlying brecciated New Harbour Group bedrock in the area between Porth Penrhyn-mawr (SH 287 852) and Porth Tywyn-mawr (SH 286 837), to the south of the present study area. These authors interpreted this diamicton as a periglacial head deposit which was reworked by the overriding Irish Sea Ice. It is possible that the lower bedrock-rich diamicton exposed in the Cemlyn Bay section is similarly a glacially reworked, pre-existing periglacial (head) deposit. Palynological data from both diamictons published by Phillips et al., (2013) demonstrate that the palynomorph assemblage is dominated by Carboniferous Densosporites spp. and Lycospora pusilla, as well as undifferentiated Quaternary pollen grains, with the lower grey diamicton containing Mesozoic (Classopollis) fauna (see Table 1 of Phillips et al., 2013). The presence of Carboniferous palynomorphs within the very locally derived New Harbour Group-rich lower diamicton is consistent with the incorporation of more 'far travelled' material into this reworked head deposit by the overriding Irish Sea ice.

In the lower part of the section through the Cemlyn Bay drumlin the diamictons are cut by two essentially subhorizontal to gently south-westerly dipping fractures which thin towards the SW and are infilled by relatively hard, laminated, red-brown sand, silt and clay (Fig. 2). The margins of these sill-like features are typically sharp and range from irregular to planar in form. These sedimentfilled fractures are coplanar with the stratification in the host diamictons suggesting that they were emplaced along this layering. The laterally more extensive of these fractures can be traced southwestwards for some 60 to $70 \mathrm{~m}$ and occurs entirely within the basal grey diamicton, approximately 20 to $30 \mathrm{~cm}$ below the contact with the overlying sandy Irish Sea Till (Fig. 2). At the northern end of the section (locations A and B on Fig. 2) this sill-like fracture is much wider (60 to $70 \mathrm{~cm}$ thick) and is composed of massive to thinly bedded, hard (compact), yellow-brown fine- to medium-sand, silt and clay (Figs. 3b, c, d and e). This fracture thins towards the SW (i.e. in a down ice direction) where it is only 10 to $20 \mathrm{~cm}$ thick, eventually appearing to pinch out or terminate in the more poorly exposed central part of the drumlin. The margins of the fracture clearly cross-cut a thin stratification present within the host grey diamicton (Fig. 3c) and locally dip at between $10^{\circ}$ to $25^{\circ}$ towards the NE (i.e. upice; see rose diagram on Fig. 2). The lamination within the sediment-fill is locally cross-cut by irregular veins of darker red-brown coarse sand to very fine gravel (Fig. 3e). A number of the sand and silt laminae possess a fine-grained carbonate cement. Thin, lenticular to irregular stringers of 
clayey diamicton locally occur within the sediments filling the hydrofracture. Striated cobbles have also been observed included within this sediment-fill (Fig. 3f).

In the central part of the section (see Fig. 2) the dip of bedding within the laminated sediment-fill is more variable ranging from $2^{\circ}$ to $20^{\circ}$, towards the ENE, SE and SW (see rose diagrams on Fig. 2). This laminated sediment-fill is up to $30 \mathrm{~cm}$ thick and crudely zoned from silt-rich at the margins, becoming progressively sandier and more thickly laminated with clay stringers towards the centre of the fracture. The margins of the fractures are typically sharp with the lamination occurring parallel to the vein margins. This lamination is variably deformed (folded, faulted) and is locally cross-cut by thin veinlets of sand. In the least deformed parts of the fracture system the lamination can traced laterally for up to 2 to $3 \mathrm{~m}$. Although the sediments filling the fracture are deformed there is very little evidence of large scale deformation of this system. In the central part of the section the upper and lower sill-like fractures are linked by a number of irregular subvertical dykelike sections composed of apparently massive sand to silty sand (Fig. 4a, b and c). Locally the lower of the two fractures appears to have been deflected around the larger boulders (Fig. 4d).

The sandy Irish Sea Till at the northern end of the section is cut by a number of more steeply inclined, southerly dipping sand and gravel-filled fractures which link into the main sill-like hydrofractures. These steeply inclined structures cut across the lithological boundary between the grey and overlying sandy diamictons indicating that their formation post-dated the deposition of at least the lower part of the of the sequence within the drumlin. The overall geometry and style of sediment-fill within the fractures cutting the diamictons at Cemlyn Bay are comparable to sedimentfilled hydrofracture systems described from other former and contemporary glacial environments (e.g. Larsen and Mangerud 1992; van der Meer et al., 1999; Rijsdijk et al., 1999; Le Heron and Etienne 2005; van der Meer et al., 2008; Phillips et al., 2012a). Consequently the sill- and dyke-like sediment-filled fractures exposed at Cemlyn Bay are interpreted as forming part of a laterally extensive hydrofracture system injected into the lower part of the drumlin.

\section{Micromorphology}

The five thin sections (E75038 to E75042; Figs. 5 to 9, respectively) obtained from different parts of the lower sill-like hydrofracture (see Fig. 2) were examined in detail allowing the pattern of sediment-fill and deformation associated with the development of this complex system to be established. For ease of description the micromorphology of the host diamicton and sanddominated sediment-fill are to be described separately.

\subsection{Micromorphology of the host diamicton}

Sample E75038 was taken across the lower boundary between the hydrofracture and the underlying grey, bedrock-rich diamicton. In thin section the diamicton is a poorly-sorted, thinly stratified, matrix-rich pebbly silty sand which possesses an open-packed, matrix-supported texture (Fig. 5). Traces of a hematitic and/or clay coating was noted on some clasts (skeleton grains).

Fine- to coarse sand, as well as small pebble-sized clasts are typically angular to subangular with a low-sphericity (see Fig. 5), indicative of a relatively short period of transport. However, rare, subrounded to well-rounded sand grains were also noted and are possibly polycyclic in origin indicating that these grains may have a longer and more complex sedimentary history. The larger 
clasts are mainly composed of rock fragments, including indurated feldspathic and quartzose sandstones (Siluro-Devonian and/or Carboniferous), micritic to microcrystalline limestone (Carboniferous), phyllonitic to schistose metamudstone (New Harbour Group), wacke sandstone, quartz-sericite rock, polycrystalline vein quartz, siltstone, very fine-grained sandstone, altered siliceous volcanic rock, calcareous sandstone and chert/siliceous cryptocrystalline rock. The finer sand and silt in the matrix is largely composed of mono- and polycrystalline quartz with minor carbonate, muscovite, opaque minerals, chlorite, epidote and plagioclase. The heterolithic nature of the clast assemblage demonstrates that although macroscopically the diamicton is dominated by very locally derived angular to subangular fragments of New Harbour Group rocks, it also contains a significant proportion of more far travelled material.

The fine stratification within the diamicton is defined by elongate, irregular ribbons and patches of clay and silt, and occurs parallel to the lower margin of the hydrofracture (Fig. 5). Internally the clay-rich layers possess a moderately to well-developed plasmic fabric which is locally deformed by a very fine-scale crenulation and narrow shears, the latter defined by thin zones which possessing a well-developed unistrial plasmic fabric. Variably developed pressure shadows are developed immediately adjacent to sand grains included within these clay-rich bands. In contrast to the clay layers, the brown, medium- to coarse-silt matrix of the diamicton lacks any obvious plasmic fabric, suggesting that it contains only minor amounts of clay minerals. However, traces of very fine, highly birefringent carbonate do occur within the matrix and these may obscure any plasmic fabric (if present).

At very low magnifications ( $x 1$ objective) the diamicton appears to be massive. However at higher magnifications ( $\times 2.5$ and $\times 10$ objectives) arcuate and circular grain alignments of silt to fine sand grade clasts were noted enclosing larger rock fragments. Two main clast microfabrics have been recognised within the diamicton. The most pronounced of these is a spaced, discontinuous foliation (S2; pale purple of Fig. 5) which dips at between $30^{\circ}$ to $40^{\circ}$ (in this plane of section) towards the northwest (up-ice direction). $\mathrm{S} 2$ is defined by relatively short domains which define a moderately well-developed planar to weakly anastomosing foliation (Fig. 5). The earlier S1 fabric (dark purple on Fig. 5) preserved within the $\mathrm{S} 2$ microlithons dips at approximately $50^{\circ}$ towards the southeast (downice). This early foliation is defined by short, irregular domains which have been variably crenulated (folded) during the imposition of S2. The spacing of the S2 domains is locally controlled by the presence of larger pebble-sized clasts, indicating that large skeleton grains were controlling the partitioning of deformation within the matrix of the diamicton. Both S1 and S2 are truncated at the boundary of the hydrofracture, clearly demonstrating that deformation resulting in the imposition of these clast microfabrics predated the brittle fracturing and formation of this sediment-filled feature.

\subsection{Micromorphology of the sediment-fill within the hydrofracture}

Samples E75038 to E75042 were collected from different parts of the hydrofracture system. In thin section they are all composed of a variably deformed, massive to finely laminated, moderately to poorly-sorted fine-sand, silty sand, silt and clay (Figs. 5 to 9). The texturally and compositionally immature sands possess an open-packed matrix- to grain-supported texture with a high intergranular porosity (up to $10 \%$ of the sediment). Angular to subangular, low sphericity silt to sand grains are mainly composed of monocrystalline quartz and variably sericitised plagioclase, as well as traces of opaque minerals, polycrystalline quartz, biotite, chlorite, muscovite, epidote/clinozoisite, microcline and altered/degraded rock fragments. Carbonate is a common minor detrital component 
with some of the laminae possessing trace amounts of a micritic carbonate cement and/or hematitic or oxidised clay rim cement.

In the least deformed sample, E75038 (Fig. 5), the outer part of the fill is composed of 2 to $10 \mathrm{~mm}$ thick, laminated clay and silty layer which appears to line the wall of the hydrofracture. The silty laminae show evidence of both normal and reverse grading. The clay-rich laminae possess a well-developed, bedding-parallel plasmic fabric which is coplanar with the margins of the hydrofracture. This fabric is variably deformed by at least one set of angular kinks developed orthogonal to the margin of the hydrofracture. The kinks are locally offset by a number of low-angle shears which record a sense of shear towards the SW. The remainder of the sediment-fill in E75038 is composed of laminated fine sand, silty sand and silt, and can be divided into six, normal graded sequences (labelled a to $f$ on Fig. 5) which possess a coarser, typically more massive, sandy base passing upwards into a finer, laminated silty top. The lamination is gently inclined towards the NE (up-ice) and is cross-cut by a number of irregular sand-filled veins (Fig. 5). These sand-filled veins also occur parallel to bedding to form a branching network which post-dates at least the early history of sediment fill within the hydrofracture. These sand veins also appear to intrude the adjacent diamicton (see Fig. 5).

Samples E75039, E75040, E75041 and E75042 show a progressive increase in the intensity of deformation (E75039 least deformed and E75042 relatively most intensively deformed) with the thinly laminated sand, silt and clay filling the hydrofracture having undergone varying degrees of tilting, folding, thrusting and ductile shearing (see Figs 6, 7, 8 and 9). In sample E75039 the diffuse lamination is steeply inclined (tilted) towards the NW (up-ice) and deformed by a set of small-scale, low-angle (c. $15^{\circ}$ to $20^{\circ}$ in this plane of section), NW-dipping thrusts (Fig. 6) with a sense of displacement towards the SW; i.e. coincident with the main ice movement direction across the area. In detail a fine-scale lamination within the silt to clay-rich layers is deformed by a set of gently inclined, open folds and crenulations which are cut through by the later thrusts. The thrust planes are diffuse structures, lacking any discrete fault plane or associated plasmic fabric. In the lower SW corner of the thin section, the thrusts are cross-cut by an irregular vein composed of massive sand (Fig. 6).

In sample E75040 the lamination is folded by a number of recumbent to gently inclined structures, with both bedding and the folds being offset by as set of low-angle to subhorizontal, SWdirected thrusts (Fig. 7). These deformation structures and bedding are cross-cut by a network of irregular veins composed of clean, matrix-poor, massive to very weakly laminated, high-porosity sand (Fig. 7). Injection of these sand-filled veins clearly post-dated folding and thrusting, and resulted in the brecciation/fragmentation of the laminated sediments filling the hydrofracture. The most prominent deformation structure present within sample E75040, however, is a lenticular or eye-shaped augen of silt and clay (Fig. 7). The shape of the augen and sigmoidal asymmetrical geometry of a well-developed plasmic fabric present within the clay (see false colour image on Fig. 7), both record a SW-directed sense of shear consistent with the sense of displacement on the thrusts. The margins of the augen are marked by a narrow zone of shearing which has been partially overprinted by the injection of the sand-filled veins.

Deformation within sample E75041 is less intense that the previous two samples and is characterised by faulting (Fig. 8). Two main sets of faults have been recognised: (i) a set of very 
steeply inclined to subvertical, NE to SW-dipping normal and reverse faults; and (ii) a set of gently to moderately SW-dipping (in this plane of section) normal (extensional) faults (Fig. 8). The low-angle normal faults downthrow to the SW and result in the minor attenuation/thinning (boudinage) of both the sand and silt layers.

In sample E75042 there is a marked contrast in the intensity of deformation recorded by the finely laminated silty sand, silt and clay in the upper part of the thin section, and the thicker finegrained sand layers towards the base of the sample. Bedding within the finer grained part of the sequence has been tilted, folded and faulted. Faulting is dominated by a set of gently NE-dipping (up-ice), SW-directed thrusts (Fig. 9). In contrast, the laminated sands which occupy the lower part of the thin section show very little evidence of deformation and contain a weakly to moderately preserved cross-lamination (Fig. 9) which records an apparent southerly (in this plane of section) palaeocurrent direction.

\section{Interpretation of the micromorphology}

The micromorphology of the bedrock-rich diamicton (E75038) forming the host to the hydrofracture system demonstrates that although it is dominated by very locally derived angular to subangular fragments of New Harbour Group rocks, it also contains a significant proportion of more far travelled material which includes Siluro-Devonian and/or Carboniferous sedimentary rocks. This supports the interpretation of Phillips et al., (2013) that the bedrock-rich diamicton on Anglesey represents a glacially reworked periglacial head deposit with the schistose rock fragments being derived locally from the underlying New Harbour Group. No Siluro-Devonian and/or Carboniferous strata are exposed in the Cemlyn Bay area, but do crop out offshore to the N/NW of Anglesey (Jackson et al., 1995) and could have been transported and incorporated into this predominantly locally derived diamicton by the overriding Irish Sea ice. The fine stratification and clast microfabrics present within the diamicton (Fig. 5) probably formed as a result of subglacial deformation imposed by the overriding ice. This deformation resulted in the shearing of the ribbons and patches of clay and silt, as well as rotation of granule to pebble-sized clasts. These larger clasts acted as rigid bodies leading to the partitioning of deformation within the matrix of the diamicton, controlling the spacing of the dominant up-ice-dipping (S2) foliation. Importantly the clast microfabrics (S1 and S2) are truncated at the boundary of the hydrofracture (see Fig. 5), clearly demonstrating that deformation of the diamicton predated hydrofracturing and the introduction of the associated sediment-fill.

Micromorphological analysis clearly reveals that the sediment-fill within the hydrofracture system cutting the lower part of the drumlin to the $W$ of Cemlyn Bay is highly complex (see Fig. 10) indicating that this structure did not form as a result of a simple 'cut-and-fill' process as described by Larsen and Mangerud (1992). The earliest phase of sedimentation within the Cemlyn Bay hydrofracture is the laminated clay and silt which line the fracture walls. The clays possess a welldeveloped plasmic fabric which is coplanar with the walls of the hydrofracture fracture. Similar clayrich linings have been described in other hydrofracture systems where they have been interpreted as having formed during the earliest stages of hydrofracturing within a zone of relatively lower overpressure close to the leading edge of the fluid front as it penetrated along the propagating fracture (Phillips et al., 2013). The plasmic fabric within the clays is thought to develop in response to 
these fine-grained sediments being 'plastered' to the fracture walls as the water-sediment mix was introduced into the widening fracture (Phillips et al., 2013).

The main part of the hydrofracture fill at Cemlyn Bay is composed of finely laminated sand, silt and clay (Fig. 10). The occurrence of graded units within these sediments is indicative of deposition by water flowing through the system, with the local preservation of a cross-lamination in the thicker sandy units (Figs. 9 and 10) indicating that flow was apparently towards the SW (i.e. down-ice). Furthermore, the presence of normal and reverse grading, and small-scale fining upward sequences (most pronounced in E75038) is indicative of sedimentation under changing flow conditions. Similar complex sedimentary fill sequences were described by Phillips et al., (2013) from a complex hydrofracture system cutting Devonian sandstone bedrock at the Meads of St John in NE Scotland. These authors interpreted these complex fills as recording multiphase sediment deposition in response to the repeated reactivation of the hydrofracture system which, therefore, remained active over a prolonged period and accommodated several phases of fluid flow (c.f. Phillips and Merritt, 2008). The presence of sedimentary structures within the hydrofracture fill at Cemlyn Bay (Figs. 5, 9 and 10) is indicative of deposition by water flowing through a fluid filled cavity or void, indicating that overpressures were high enough and sustained long enough to maintain an 'open drainage system' within the hydrofracture during fluid flow (Phillips et al., 2013). As the overpressures began to fall towards the end of a flow event the hydrofracture would have closed, constricting the open drainage system and thereby shutting off both fluid flow and sedimentation, and leading to compaction and dewatering of the sediment fill, and the formation of a beddingparallel plasmic fabric (E75042) within the clay laminae. The complexity of the sediment-fill within the hydrofracture exposed at Cemlyn Bay indicates that this sequence of events occurred several times.

Studies of the hydrogeology of contemporary glaciers and ice sheets have demonstrated that meltwater discharge varies on a range of scales from daily, yearly, through to much longer decadal cycles (see Benn and Evans, 2010; Russell et al., 2010; Boulton, 2006 and references therein). Such variations lead to the repeated build up of meltwater content and pressures in the subglacial environment which can result not only in the initial propagation of the hydrofracture system, but also the periodic reactivation of these features which act as a 'safety valve' (van der Meer et al., 2008; Phillips et al., 2013) releasing pressure built-up within the subglacial hydrogeological system. These 'pressure release events' are likely to be separated by periods of quiescence when the hydrofracture systems are inactive (Phillips et al., 2013). Importantly, the repeated reactivation of a hydrofracture could lead to the erosion/'flushing' of earlier fills (in particular less cohesive matrix-poor sands and silts) leading to erosion within some parts of the system, rather than sediment deposition (Phillips et al., 2013). Consequently, the sediment-fill present within the hydrofracture exposed near Cemlyn Bay may only preserve part of the record of this style of subglacial sedimentation.

The finely laminated sediments filling the Cemlyn Bay hydrofracture system are variably deformed with the intensity of deformation apparently increasing towards the SW (see Fig. 10). This deformation comprises an early phase of ductile shearing accompanied by folding and plasmic fabric development, followed by later brittle faulting which was dominated by low-angle, SW-directed thrusting (Figs. 6, 7, 8, 9 and 10). The style of this displacement indicates that it was a result of mixed mode failure with normal and shear stresses acting simultaneously (Belayneh, 2004). All the 
structures record a similar SW-directed sense of shear/displacement, consistent with the overall SWdirected flow of ice across NW Anglesey and indicating that they formed in response to the same overall stress regime. The hydrofracture clearly cross-cuts the stratification (Fig. 3c) and clast microfabrics (Figs. 5 and 10) present in the host diamicton indicating that ductile shearing and brittle faulting of the sediments filling the hydrofracture post-dated deformation of at least the lower part of the stratified diamicton sequence. Consequently, deformation of the sediment-fill is likely to have occurred during hydrofracturing as a result of SW-directed shear imposed during either the initial stages of reactivation of the hydrofracture and/or as the walls of the hydrofracture begin to close towards the later stages of a flow event. The coincidence of the shear direction recorded by the folds, shears and thrusts, and regional ice flow direction suggests that deformation within the hydrofracture occurred beneath the advancing Irish Sea ice. The laminated sediments filling the hydrofracture would represent a zone of weakness within the bed beneath the overriding Irish Sea ice leading to the partitioning of subglacial deformation along this feature. The stresses required to cause failure along the hydrofracture plane are lower than those for over-consolidated till. The transition from early ductile deformation (shearing and folding) to later brittle thrusting may have accompanied the dewatering of the sediments due to an increase in overburden pressure leading to compaction as the sides of the hydrofracture closed after a flow event.

The early phases of sedimentation and subsequent deformation of the sediment-fill were largely post-dated by the injection of a network of cross-cutting to layer-parallel sand-filled veins (Figs. 5, 6, 7, 8 and 9). The thickness/volume and intensity of these late-stage veins appears to increase towards the SW, i.e. in a down-ice direction (see Fig. 10). In samples E75039 (Fig. 6) and E75041 (Fig. 9) the sand veins are locally cross-cut by the low-angle thrusts and normal faults indicating that liquefaction and injection of the massive, clean sand coincided with at least the later stages of deformation. This late stage intrusion of the sand veins into the hydrofracture clearly denotes a marked change in the style of propagation/reactivation of this structure. One possibility is that during the earlier stages of hydrofracture evolution the overpressures responsible for the reactivation of the system were high enough to facilitate the reopening of an "open drainage system" allowing the repeated, incremental deposition of the laminated sediment-fill (see Fig. 5). However, in later stages the porewater pressures may potentially have been much lower and, therefore, insufficient to completely reopen the system. As a result these lower magnitude flow events led to the fracturing or locally more intense brecciation of the pre-existing sediment-fill and injection of structureless (massive) clean sand as result of the cut-and-fill mechanism proposed by Larsen and Mangerud (1992).

In summary, the detail analysis of the micromorphology of the sediment-fill within the Cemlyn Bay hydrofracture system has allowed its evolution to be divided into three main stages:

- Stage 1 - propagation and repeated reactivation of the hydrofracture system leading to the deposition of a laminated sediment-fill by water flowing through an open drainage system, possibly as a result of the periodic build-up and release of relatively high overpressures within the subglacial hydrogeological system;

- Stage 2 - initial ductile deformation followed by later brittle thrusting of the sediment-fill in response to SW-directed shear imposed by the overriding Irish Sea ice; 
- Stage 3 - late stage fracturing and brecciation of the pre-existing sediment-fill and injection of veins of clean sand possibly as a result of falling overpressures accompanying the shutdown of the hydrofracture system.

\section{Discussion: evidence for hydrofracturing in response to the development of an overpressurised subglacial meltwater system during drumlin formation}

\subsection{Hydrofracturing in a subglacial setting during drumlin formation}

The results of the detailed field and micromorphological study of the glacigenic sediments exposed at Cemlyn Bay are consistent with the laterally extensive network of sediment-filled fractures which cut this sequence representing a hydrofracture system. The complex sediment fill within this hydrofracture system records the repeated injection of an overpressurised mix of sand, silt, clay and water into the lower part of a sequence of stratified diamictons forming the core of an elongate drumlin. Kinematic indicators (folds, clay-silt augen; Figs 7 and 10) present within the variably deformed sediment-fill to this fracture system record a SW-directed sense of movement, coincident with the regional ice flow direction across NW Anglesey. This microstructural evidence can be used to demonstrate that the Irish Sea ice was still active during the development of the hydrofracture system within its bed, with subglacial deformation imposed by the overriding ice probably aiding the lateral propagation of this system. Importantly there is no geomorphological evidence (e.g. recessional moraines) on Anglesey for the Irish Sea ice having undergone active retreat, rather the landform assemblage zones developed on the island preserve a record of subglacial landform development (e.g. drumlins) and erosion (e.g. bedrock cut meltwater channels) (Thomas and Chiverrell, 2007; Phillips et al., 2010). Consequently, it is concluded that hydrofracture development at the Cemlyn Bay site occurred within the bed of the Irish Sea Ice Stream whilst this relatively faster flowing corridor of ice was actively overriding the island of Anglesey (see section 7.2).

Figure 11a shows the relationship(s) between the orientation of the hydrofracture system and shear imposed by the overriding Irish Sea ice. The variation in the orientation of the main sills and dykes which form the hydrofracture system is consistent with their formation having been principally controlled by $Y$ and R-type Riedel shears (Fig. 11a), respectively, with these shears having developed in response to an overall simple shear subglacial deformation model (subglacial shear zone). The change from NE-dipping sills which feed the hydrofracture system at the northern-end of the section, to gently SW inclined in the central part of the drumlin can be related to a change in the orientation of the imposed shear as the Irish Sea ice continued to override the drumlin (Fig. 11a). At the northern end of the section the ice would have been forced to 'climb' up the steep stoss-side of the landform. Consequently, the resulting subglacial shear zone developed within the underlying stratified diamictons would have been inclined, dipping towards the N/NE (i.e. up-ice). In the central part of the landform the subglacial shear zone formed beneath the overriding ice would have been subhorizontal to gently S/SW-dipping as the Irish Sea ice descended the lee slope of the landform. The geometry of the hydrofracture in this area is once again consistent with the main feeder sills having exploited the $Y$ shears, with short up-ice and down-ice dipping sections of the hydrofracture occurring coplanar to the associated R and P-type shears (Fig. 11a). Opening of the subvertical to steeply down-ice dipping dyke sections of the hydrofracture would have been assisted by the 
extensional geometry of the controlling R/R' shears (see Fig. 11a). In contrast, opening of the main feeder sills which exploited the $Y$ shears would have had to overcome the overburden (confining) pressures exerted by the overlying glacigenic sequence and overriding ice. As a result the overpressures within the subglacial hydrogeological system which led to not only initial fracture propagation, but the subsequent repeated reopening and sedimentation within the Cemlyn Bay hydrofracture system, must have repeatedly exceeded this confining pressure. This is more likely to be achieved during the later stages of the evolution of the ice stream as it began to thin (see section 7.2).

Although a subglacial setting beneath the active Irish Sea Ice Stream can be argued for the Cemlyn Bay hydrofracture system its relationship to the formation of the 'host' drumlin (see Fig. 1e) remains uncertain. Field evidence clearly shows that the formation of the interconnected system of gently down-ice dipping to subhorizontal sills and more steeply inclined dyke-like components of the hydrofracture system post-dated the emplacement of at least the lower part of the glacial sequence (Fig. 2); this includes the sandy Irish Sea Till which was deposited by the Irish Sea ice as it overrode Anglesey. If the hydrofracture system predated drumlin formation, or had formed early during the development of these landforms, these sediment-filled features would have represented major planes of weakness within the deforming bed of the ice sheet. As a result, deformation would have been focused along these planes leading to thrusting and the potential detachment of the developing landform from the underlying bed and its transport down-ice (Stages 1 to 3 on Fig. 11b). Thrust-related detachment/decoupling would have had a profound effect on the stability, morphology and distribution of the landforms, and could potentially result in the 'piggy backing' or 'stacking' of several drumlins (Stage 4 on Fig. 11b). Although complex 'double' landforms with undulating crest lines do occur in the study area (see Fig. 1d), recent detailed geomorphological mapping of Anglesey carried out by the British Geological Survey has revealed that these complex landforms are relatively uncommon. Although there is microscale evidence of SW-directed shearing having been accommodated by the sediment fill within the hydrofracture system, there is no evidence of significant translation across the hydrofractures exposed in the Cemlyn Bay section, indicating that they do not represent significant detachments (thrusts). Consequently, the hydrofracturing of the stratified diamicton sequence within the Cemlyn Bay drumlin is thought to have occurred during either the later stages of, or post landform development.

\subsection{Relative timing of hydrofracturing to the shutdown of the Irish Sea Ice Stream}

Hydrofracture systems from glacial environments described in the literature (e.g. van der Meer et al., 1999; van der Meer et al., 2008; Phillips et al., 2013) are typically developed with an ice-marginal to sub-marginal setting providing an 'escape route' for the overpressurised meltwater from beneath the ice forming the 'burst out' structures of Benediktsson et al. (2008). However, field and micromorphological evidence presented here indicates that hydrofracturing at the Cemlyn Bay site occurred whilst the Irish Sea ice was still actively overriding the area and coupled to its bed allowing shear to be transmitted into this substrate; i.e. hydrofracturing occurred under full subglacial conditions. A subglacial setting is also indicated by the geomorphological record on Anglesey which lacks any evidence of active ice-margin retreat (Thomas and Chiverrell, 2007; Phillips et al., 2010). Consequently, it is concluded that hydrofracture development at the Cemlyn Bay site occurred within the bed of the Irish Sea Ice Stream whilst this relatively faster flowing corridor of ice was actively overriding the island of Anglesey. Any overpressurised meltwater system developed at this 
stage would have been effectively constrained beneath the ice and would have led to hydrofracturing of the underlying bed.

Hydrofracturing of both the glacigenic sedimentary sequence and underlying Monian Supergroup bedrock have been described elsewhere on Anglesey (e.g. Harris, 1991; Phillips et al., 2013). Harris (1991) recorded open and sand-filled joints (hydrofractures) within the bedrock cores from boreholes in the Wylfa Head area to a depth of 20 m. Phillips et al. (2012a) argued that these hydrofractures plus other examples cutting the New Harbour Group bedrock between Porth Penrhyn-mawr (SH 287 852) and Porth Tywyn-mawr (SH 286 837) in western Anglesey provided clear evidence for the existence of an overpressurised hydrogeological system beneath the Irish Sea Ice Stream. The development of such a system beneath this ice stream is supported by the presence of a network of subglacial meltwater channels cut into the bedrock in the western part of the study area (see Fig. 1c) and elsewhere across Anglesey (Thomas and Chiverrell, 2007; Phillips et al., 2010; Phillips et al., 2012b). Pressurised meltwater systems beneath former and contemporary ice streams are thought to represent one of the main factors controlling fast ice flow (Clark and Stokes, 2001; Bennett, 2003; Bamber et al., 2003). The development of such a system beneath the Irish Sea Ice Stream would have facilitated its overriding of Anglesey as this ice stream continued to expand and extend further southward to its maximum extent at the Isles of Scilly (Hiemstra et al., 2006). However, the relative timing of hydrofracturing with respect to the evolution of the Irish Sea Ice Stream remains uncertain.

It is likely that pressurised meltwater flow within the proposed subglacial hydrogeological system would have been either preferentially concentrated along the ice-bed interface flowing around or over the drumlins, thereby facilitating basal sliding, or concentrated within the network of subglacial meltwater channels. The volume of meltwater moving through the bed was probably much lower than that along the ice-bed interface or subglacial channels, and would have been strongly controlled by the porosity and permeability of the Irish Sea Till. The presence of hydrofractures injected into the bed of the Irish Sea ice clearly indicates that the hydrostatic pressures within the subglacial meltwater system periodically exceeded the cohesive strength of the Irish Sea Till and underlying Monian Supergroup bedrock; effectively acting as a 'pressure release' or 'safety valve' to the system (cf. van der Meer et al., 2008; Phillips et al., 2013). Evidence presented above (section 7.1) suggests that hydrofracturing of the glacigenic sequence at Cemlyn Bay may have occurred either after (post) or during (syn) the later stages of drumlin formation. This hydrofracture propagated SW-wards (down-ice) and was initiated on the steep, up-ice side of the drumlin (see Figs. $1 \mathrm{~d}$ and 11 ) with shear imposed by the overriding ice facilitating the opening of this system. As they developed the drumlins beneath the Irish Sea Ice Stream would have strongly influence or even impeded meltwater flow along the ice-bed interface. As a result hydrostatic pressure would have probably built up on the up-ice side of these subglacial landforms, leading to the localised overpressurisation of the hydrogeological system and hydrofracturing of the bed. The complex nature of the sediment-fill within the Cemlyn Bay hydrofracture suggests that over-pressurisation and reactivation of these structures occurred repeatedly, possibly reflecting periodic fluctuations in the volumes of meltwater flowing through the subglacial hydrogeological system. This increased variability in the hydrostatic pressure and potentially the volume of meltwater flowing through the subglacial hydrogeological system may possibly suggest that it was becoming progressively unstable. The reopening of the subhorizontal to gently dipping sills which fed the hydrofracture system requires that overpressures repeatedly exceeded the confining pressure exerted by the overriding 
Irish Sea ice. As noted above this is more easily achieved during the later stages of the evolution of the ice stream as it began to thin leading to a reduction in the confining pressure exerted upon the sediments within its bed. Consequently, it is possible that hydrofracturing observed at the Cemlyn Bay site occurred in response to the release/migration of overpressurised meltwater within the bed of the Irish Sea ice, potentially recording the destabilisation of the subglacial hydrogeological system, cessation of subglacial landform development and local shutdown of the Irish Sea Ice Stream on Anglesey.

\section{Conclusions}

A detailed macro- and microscale sedimentological and structural studies of a complex hydrofracture system and host diamictons exposed to the west of Cemlyn Bay (NW Anglesey, N Wales) clearly demonstrates that this laterally extensive network of sand, silt and clay filled system was active over a prolonged period, and developed beneath the overriding Irish Sea ice. The hydrofracture system is developed within the lower part of a stratified sequence of diamictons forming the core to an elongate NE-SW-trending drumlin. The sedimentary fill to this hydrofracture system is variably deformed with the resultant folds, thrusts and augen recording a SW-directed sense of shear, consistent with the regional ice flow direction across this part of NW Anglesey. Importantly there is no geomorphological evidence on Anglesey for the Irish Sea ice having undergone active retreat, rather the landform assemblage zones developed on the island preserve a record of subglacial erosion and landform development. Consequently, it is concluded that hydrofracturing at the Cemlyn Bay site occurred within the bed of the Irish Sea Ice Stream whilst this relatively faster flowing corridor of ice was active. Deformation imposed by the overriding ice led to the development of a subglacial shear zone which facilitated the propagation of the hydrofracture system with the laterally extensive feeder sills occurring parallel to Y-type Riedel shears and subsequent deformation of the sediment-fill. Although a subglacial setting beneath the active Irish Sea Ice Stream can be argued for the Cemlyn Bay hydrofracture system its relationship to the formation of the 'host' drumlin remains uncertain. Hydrofracturing clearly post-dated the deposition of at least the lower part of the glacigenic sequence, including the Irish Sea Till which was laid down by the Irish Sea ice as it overrode Anglesey. Consequently, the initial propagation and subsequent evolution of this hydrofracture system is thought to have occurred during either the later stages of, or post-drumlin development. Evidence from the Cemlyn Bay site can be used to suggest that hydrofracturing occurred in response to the migration of overpressurised meltwater within the bed of the Irish Sea ice possibly accompanying the local thinning and shutdown of the Irish Sea Ice Stream on Anglesey and cessation of subglacial landform development.

\section{Acknowledgements}

This work forms part of ERP's IMP research project and the Geology and Landscape of Wales programme of the British Geological Survey. Jonathan Lee, Rhian Kendall and Jez Everest are thanked for discussions in the field and comments on an earlier version of this manuscript. John Fletcher (BGS thin sectioning laboratory, Keyworth) is acknowledged for his expertise in making the thin sections. Simon Carr and Jaap van der Meer are thanked for their constructive reviews of this paper. ERP is an associate member of the Centre for Micromorphology, Queen Mary, University 
London. This paper is published with the permission of the Executive Director of the British Geological Survey (NERC).

\section{References}

Bamber, J.L., Baldwin, D.J., Gogineni, S.P. 2003. A new bed elevation data set for modelling the Greenland ice sheet. Annals of Glaciology 37, 351-356.

Belayneh, M. 2004. Palaeostress orientation inferred from surface morphology of joints on the southern margin of the Bristol Channel Basin, UK. In Cosgrove J.W., Engelder, T. (eds) The Initiation, Propagation and Arrest of Joints and Other Fractures, 117-128. Geological Society of London Special Publication 231.

Benediktsson, I.O., Möller, P., Ingólfsson, O., van der Meer, J.J.M., Kjær, K.H., Krüger, J. 2008. Instantaneous end moraine and sediment wedge formation during the 1890 glacier surge of Brúarjökull, Iceland. Quaternary Science Reviews 27, 209-234.

Benn, D.I., Evans, D.J.A. 2010. Glaciers and Glaciation (Second Edition). 802 pp. Hodder Education.

Bennett, M.R. 2003. Ice streams as the arteries of an ice sheet: their mechanics, stability and significance. Earth-Science Reviews 61, 309-339.

Boulton, G.S. 2006. Glaciers and their coupling with hydraulic and sedimentary processes. In Knight, P.G. (ed.) Glacier Science and Environmental Change, 3-22. Blackwell, Oxford.

Broster, B.E. 1991. Glacitectonic deformation in sediment and bedrock, Hat Creek, British Columbia. Geographie physique et Quaternaire 45, 5-20.

Broster, B.E., Seaman, A.A. 1991. Glacigenic rafting of weathered granite: Charlie Lake, New Brunswick. Canadian Journal of Earth Sciences 28, 649-654.

von Brunn, V., Talbot, C.J. 1986. Formation and deformation of subglacial intrusive clastic sheets in the Dwyka formation of northern Natal, South Africa. Journal of Sedimentary Petrology 56, 35-44.

Burbridge, G.H., French, H.M., Rust, B.R. 1988. Water escape fissures resembling ice wedge casts in late Quaternary subaqueous outwash near St. Lazare, Quebec, Canada. Boreas 17, 33-40.

Burke. E.R., Phillips, E.R., Lee, J.R., Wilkinson, I.P. 2009. Imbricate thrust stack model for the formation of glaciotectonic rafts: an example from the Middle Pleistocene of north Norfolk, UK. Boreas 38, 620-637.

Christiansen, E.A., Gendzwill, D.J., Meenely, W.A. 1982. Howe Lake: a hydrodynamic blowout structure. Canadian Journal of Earth Sciences 19, 1122-1139.

Clark, C.D., Stokes, C.R. 2001. Extent and basal characteristics of the M'Clintock Channel Ice Stream. Quaternary International 86, 81-101.

Clark, C.D., Anna L.C. Hughes, A.C.L., Greenwood, S.L., Jordan C., Sejrup, H.P. 2012. Pattern and timing of retreat of the last British-Irish Ice Sheet. Quaternary Science Reviews 44, 112-146. 
Collins, A., Buchan, C., 2004. Provenance and age constraints of the South Stack Group, Anglesey, UK: U-Pb SIMS detrital zircon data. Journal of the Geological Society of London 161, 743-746.

Dionne, J.-C., Shilts, W.W. 1974. A Pleistocene clastic dike, Upper Chaudie re Valley, Quebec. Canadian Journal of Earth Sciences 11, 1594-1605.

Dreimanis, A. 1992. Downward injected till wedges and upward injected till dykes. Sveriges Geologiska Undersøgelse, Serie Ca 81, 91-96.

Dreimanis, A., Rappol, M. 1997. Late Wisconsinan sub-glacial clastic intrusive sheets along Lake Erie bluffs, at Bradtville, Ontario, Canada. Sedimentary Geology 111, 225-248.

Evans, D.J.A., Ó Cofaigh, C. 2003. Depositional evidence for marginal oscillations of the Irish Sea ice stream in southeast Ireland during the last glaciation. Boreas 32, 76-101.

Evans, D.J.A., Benn, D.I. 2004. A practical guide to the study of glacial sediments. Arnold, London, pp 266.

Goździk, J., van Loon, A.J. 2007: The origin of a giant downward directed clastic dyke in a kame (Be1chatow mine, central Poland). Sedimentary Geology 193, 71-79.

Greenly, E., 1919. The geology of Anglesey. Memoir (District) Geological Survey of Great Britain. HMSO, London 980.

Harris, C., 1991. Glacial deposits at Wylfa Head, Anglesey, North Wales: evidence for Late Devensian deposition in a non-marine environment. Journal of Quaternary Science 6, 67-77.

Helm, D.G., Roberts, B., 1984. The origin of late Devensian sands and gravels, southeast Anglesey, N. Wales. Geological Journal 19, 33-55.

Hiemstra, J.F., Evans, D.J.A., Scourse, J.D., McCarroll, D., Furze, M.F.A., Rhodes, E. 2006. New evidence for a grounded Irish Sea glaciation of the Isles of Scilly, UK. Quaternary Science Reviews, 25, 299-309.

Howells, M.F. 2007. British Regional Geology: Wales. British Geological Survey, Keyworth, Nottingham.

Jackson, D.I., Jackson, A.A., Evans, D., Wingfield, R.T.R., Barnes, R.P., Arthur, M.J. 1995. The Geology of the Irish Sea. United Kingdom Offshore Regional Report 20-24. London, British Geological Survey, HMSO.

Kjær, K.H., Larsen, E., van der Meer, J.J.M., Ingólfsson, O., Krüger, J. Benediktsson, I.O., Knudsen, C.G., Schomacker, A. 2006. Subglacial decoupling at the sediment/bedrock interface: a new mechanism for rapid flowing ice. Quaternary Science Reviews 25, 2704-2712.

Larsen, E., Mangerud, J. 1992. Subglacially formed clastic dykes. Sveriges Geologiska Undersokning Series Ca 81, 163-170.

Le Heron, D.P., Etienne, J.L. 2005. A complex subglacial clastic dyke swarm, Sólheimajökull, southern Iceland. Sedimentary Geology 181, 25-37. 
Maltman, A.J., 1977. The Serpentinites and related rocks of Anglesey. Geological Journal 12, 113128.

McCabe, A.M., Dardis, G.F. 1994. Glaciotectonically induced water-through flow structures in a Late Pleistocene drumlin, Kanrawer, County Galway, western Ireland. Sedimentary Geology 91, 173-190.

McCarroll, D., 2005. North-west Wales. In Lewis, C.A., Richards, A.E., (eds.) The Glaciations of Wales and Adjacent Areas. Logaston Press 27-40.

Menzies, J. 2000. Micromorphological analyses of microfabrics and microstructures indicative of deformation processes in glacial sediments. In Maltman, A.J., Hubbard, B. \& Hambrey, M.J. (eds.): Deformation of Glacial Materials, 245-257. Geological Society of London Special Publication 176.

Merritt, J.W., Auton, C.A., 2000. An outline of the lithostratigraphy and depositional history of Quaternary deposits in the Sellafield district, west Cumbria. Proceedings of the Yorkshire Geological Society 53, 129-154.

Moran, S.R., Clayton, L., Hooke, R.L., Fenton, M.M., Andriashek, L.D. 1980. Glacier-bed landforms of the prairie region of North America. Journal of Glaciology 25, 457-476.

Phillips, E.R., 1989. The Geology of the Monian Supergroup, Western Anglesey, North Wales. Unpublished PhD thesis, University of Wales, Cardiff, pp 470..

Phillips, E.R., 1991a. The lithostratigraphy, sedimentology and tectonic setting of the Monian Supergroup, western Anglesey, North Wales. Journal of the Geological Society of London 148, 10791090.

Phillips, E.R., 1991b. Progressive deformation of the South Stack and New Harbour Groups, Holy Island, western Anglesey, North Wales. Journal of the Geological Society of London 148, 1091-1100.

Phillips, E.R., Evans, D.J.A., Auton, C.A. 2002. Polyphase deformation at an oscillating ice margin following the Loch Lomond Readvance, central Scotland, UK. Sedimentary Geology 149, 157-182.

Phillips, E., Merritt, J. 2008. Evidence for multiphase water-escape during rafting of shelly marine sediments at Clava, Inverness-shire, NE Scotland. Quaternary Science Reviews 27, 988-1011.

Phillips, E.R., van der Meer, J.J.M., Ferguson, A. 2010a. A new 'microstructural mapping' methodology for the identification and analysis of microfabrics within glacial sediments. Quaternary Science Reviews. 30, 2570-2596.

Phillips, E.R., Everest, J., Diego Diaz-Doce, D. 2010b. Bedrock controls on subglacial landform distribution and geomorphological processes: Evidence from the Late Devensian Irish Sea Ice Stream. Sedimentary Geology. 232, 98-118.

Phillips, E., Lee, J.R., Riding, J.B., Kendall, R., Hughes, L. 2012a. Periglacial disruption and subsequent glacitectonic deformation of bedrock: an example from Anglesey, North Wales, UK. Proceedings of the Geologists' Association. Proceedings of the Geologists Association. In Press. http://dx.doi.org/10.1016/i.pgeola.2012.08.006. 
Phillips, E.R., Ritchie, C., Oliver, L., Mann, E., Everest, J., Diaz Doce, D. 2012b. Anglesey (Ynys Môn): a landscape carved by ice. Web delivery i-map. British Geological Survey (available on line at http://www.bgs.ac.uk/discoveringGeology/geologyOfBritain/anglesey/home.html).

Phillips, E., Everest, J., Reeves, H. 2013. Micromorphological evidence for subglacial multiphase sedimentation and deformation during overpressurized fluid flow associated with hydrofracturing. Boreas. 42, 395-427.

Roberts, D.H., Dackombe, R.V., Thomas, G.S.P. 2007. Palaeo-ice streaming in the central sector of the British-Irish Ice Sheet during the Last Glacial Maximum: evidence from the northern Irish Sea Basin. Boreas 36,115-129.

Rijsdijk, K.F., Owen, G., Warren, W.P., McCarroll, D., van der Meer, J.J.M. 1999. Clastic dykes in overconsolidated tills: evidence for subglacial hydrofracturing at Killiney Bay, eastern Ireland. Sedimentary Geology 129, 111-126.

Russell, A.J., Tweed, F.S., Roberts, M.J., Harris, T.D., Gudmundsson, M.T, Knudsen, Ó, Marren, P.M, 2010. An unusual jökulhlaup resulting from subglacial volcanism, Sólheimajökull, Iceland, Quaternary Science Reviews, 29, 1363-1381.

Scourse, J.D., 1991a. Late Pleistocene stratigraphy and palaeobotany of the Isles of Scilly. Philosophical Transactions of the Royal Society of London B334, 405-448.

Scourse, J.D., 1991b. Glacial deposits of the Isles of Scilly. In Ehlers, J., Gibbard, P.L., Rose, J., (eds.) Glacial Deposits in Great Britain and Ireland. A.A. Balkema, Rotterdam 291-300.

Shackleton, R.M., 1975. Precambrian rocks of Wales. In Harris, A.L., et al., (eds.) A correlation of the Precambrian rocks in the British Isles. Geological Society of London, Special Report 6, 76-82.

Stokes, C.R., Clark, C.D., 2001. Palaeo-ice streams. Quaternary Science Reviews 20, 1437-1457.

Thomas, G.S.P., Chiverrell, R.C., 2007. Structural and depositional evidence for repeated ice-marginal oscillation along the eastern margin of the Late Devensian Irish Sea Ice Stream. Quaternary Science Reviews 26, 2375-2405.

van Landeghem, K.J.J., Wheeler, A.J., Mitchell, N.C., 2009. Seafloor evidence for palaeo-ice streaming and calving of the grounded Irish Sea Ice Stream: Implications for the interpretation of its final deglaciation phase. Boreas 38, 119-131.

van der Meer, J.J.M. 1987. Micromorphology of glacial sediments as a tool in distinguishing genetic varieties of till. In Kujansuu, R., Saarnisto, M. (eds) INQUA Till Symposium, Finland 1985, 77-89. Geological Survey of Finland, Special Paper 3.

van der Meer, J.J.M. 1993. Microscopic evidence of subglacial deformation. Quaternary Science Reviews 12, 553-587.

van der Meer, J.J.M. 1996: Micromorphology. In Menzies, J. (ed.): Glacial Environments: Volume 2; Past Glacial Environments - Processes, Sediments and Landforms, 335-355. Butterworth and Heinemann, Oxford. 
van der Meer, J.J.M., Kjær, K., Krüger, J. 1999. Subglacial water-escape structures, Slettjökull, Iceland. Journal of Quaternary Science 14, 191-205.

van der Meer, J.J.M., Kjær, K.H., Krüger, J., Rabassa, J., Kilfeather, A.A. 2008. Under pressure: clastic dykes in glacial settings. Quaternary Science Reviews 28, 708-720.

Vaughan-Hirsch, D. P., Phillips, E., Lee, J. R., Hart, J. K. 2013. Micromorphological analysis of polyphase deformation associated with the transport and emplacement of glaciotectonic rafts at West Runton, north Norfolk, UK. Boreas 42, 376-394.

\section{Figures}

Fig. 1. Map of the British lles showing location of Anglesey, NW Wales and the approximate limit of the British and Irish Ice Sheet. Also shown is the proposed maximum extend of Irish Sea Ice Stream; (b) Map of Anglesey showing the location of the study area and extend of the three landform assemblage zones (Thomas and Chiverrell 2007; Phillips et al., 2010); (c) Simplified superficial map of the Cemlyn Bay area of NW Anglesey showing the distribution of the main glacigenic sedimentary units and landforms; (d) Elongate drumlin developed on the southern side of the Cemlyn Nature Reserve (note presence of an undulating crest line to the drumlin); and (e) Photomontage of the exposed section through an elongate, NE-SW-trending drumlin located to the west of Cemlyn Bay (see Fig. 1c).

Fig. 2. Photomontage of the laterally extensive hydrofracture system exposed towards the base of the Cemlyn Bay drumlin section. Also shown are the locations of the five samples taken for thin sectioning and micromorphological analysis, and lower hemisphere stereographic projections of dip and dip azimuth data obtained for the margin of the hydrofracture and bedding/lamination developed within this complex system.

Fig. 3. (a) Striated boulder within the lower grey diamicton which is rich in very locally derived schistose metasedimentary New Harbour Group rock fragments: (b) Thinly bedded sand, silt and clay filling a 15 to $20 \mathrm{~cm}$ wide hydrofracture; (c) Sediment-filled hydrofracture cross-cutting a locally developed fine-scale stratification developed within the lower grey diamicton; (d) Diffuse clay-rich layers and stringers within sediment-filled hydrofracture; (e) Veins of coarse sand to very fine gravel cross-cutting earlier developed sand-rich fill within the hydrofracture system; and (f) Striated cobble included within massive, to weakly laminated sediment-fill to hydrofracture.

Fig. 4. (a) and (b) Irregular, subvertical, sand-filled 'dyke' linking two 'sill'-like gently inclined sediment-filled hydrofractures; (c) Diffuse Irregular, subvertical, sand-filled 'dyke' cutting lower, grey diamicton; and (d) Sediment-filled hydrofracture 'deflected' around a large boulder of New Harbour Group schist included within the lower grey diamicton.

Fig. 5. Microstructural map and high resolution scan of thin section of Cemlyn sample 1 (BGS registration number E75038) (see text for details). The orientation of the long axes of the fine sand to pebble sized clasts included within the diamicton are shown in the attached rose diagram. The sedimentary sequence present within the hydrofracture is divided into a series ((a) to (f)) of massive to laminated, upward fining sequences showing that this hydrofracture system accommodated several phases of fluid flow. 
Fig. 6. Microstructural map and high resolution scan of thin section of Cemlyn sample 2 (BGS registration number E75039) (see text for details). The orientation of the microscale faults and shears which offset bedding within this massive to weakly laminated, fine sand dominated hydrofracture fill are shown in the attached rose diagram. These faults and shears record a sense of displacement towards the SW, consistent with the overall ice movement direction in the Cemlyn Bay area. Deformation of the finely laminated silt and clay layer (centre left) resulted in the development of fine-scale, open, crenulation style folds. The axial planes of these microscale folds are coplanar with the thrusts and shears indicating that they probably formed in response to the same overall stress regime.

Fig. 7. Microstructural map, false colour image and high resolution scan of thin section of Cemlyn sample 3 (BGS registration number E75040) (see text for details). The originally laminated silt and clay and massive sand fill to the hydrofracture has been sheared resulting in the development of a asymmetrical 'augen' and subhorizontal to gently NE-dipping (in this plane of section) thrusts and shears. These deformation structures record a sense of shear towards the SW, consistent with the overall ice movement direction in the Cemlyn Bay area. The sedimentary layering and deformation structures were later cross cut by a complex network of sand-filled veins.

Fig. 8. Microstructural map, false colour image and high resolution scan of thin section of Cemlyn sample 4 (BGS registration number E75041) (see text for details). Bedding/layering within this sample is deformed by a set of low-angle SW-dipping (in this plane of section) extensional faults ( $R$ shears) and more steeply SW-dipping normal faults ( $R^{\prime}$ shears). The low-angle extensional faults (lags) record a sense of shear towards the SW, consistent with the overall ice movement direction in the Cemlyn Bay area.

Fig. 9. Microstructural map, false colour image and high resolution scan of thin section of Cemlyn sample 5 (BGS registration number E75042) (see text for details). Bedding/layering within this sample is deformed by a set of low-angle NW-dipping (in this plane of section) thrust faults and more steeply NW-dipping normal faults. The SW-directed sense of movement on the thrusts is consistent with the overall ice movement direction in the Cemlyn Bay area. The bedding/lamination in the upper part of the thin section is moderately inclined (tilted) towards the SW. The central and lower parts of the thin section are intruded by a number of veins/layers of massive sand.

Fig. 10. Diagram showing the relative positions and overall interpretation of the thin sections within the hydrofracture system exposed to the west of Cemlyn Bay. Micromorphological analysis reveals the following: (i) the hydrofracture fill is complex, comprising bedded/laminated sand, silt and clay; (ii) there is an overall increase in the intensity of the deformation towards the SW, i.e. in a down ice direction; (iii) early ductile shearing of the laminated sediment-fill was followed by later brittle faulting; (iv) deformation structures record a consistent SW-directed sense of shear/displacement consistent with the main ice movement direction across the Cemlyn Bay area; and ( $v$ ) earlier ductile folding and brittle thrusting was followed by the injection of a complex network of sand-filled veins (see text for details).

Fig. 11. (a) Diagram showing the relationship between the orientation of the sill and dyke-like sections of the hydrofracture system and shearing imposed by the overriding Irish Sea Ice. The diagram shows that in the variation in the orientation of the main sill-like feeders and dyke-like sections of the hydrofracture system can be related to the orientation of in particular $Y$ and R-type 
Riedel shears developed in response to an overall simple shear deformation model; and (b) Conceptual model showing how a laterally extensive hydrofracture system can potentially developed into a detachment, destabilising the drumlin leading to its detachment, down-ice transport and accretion onto the stoss side of a more stable landform (see text for details). The 'piggybacking' of the detached drumlin onto a more stable landform may lead to the development of complex subglacial landforms, for example drumlinoid features with undulating crest lines (see Fig. 1d). 


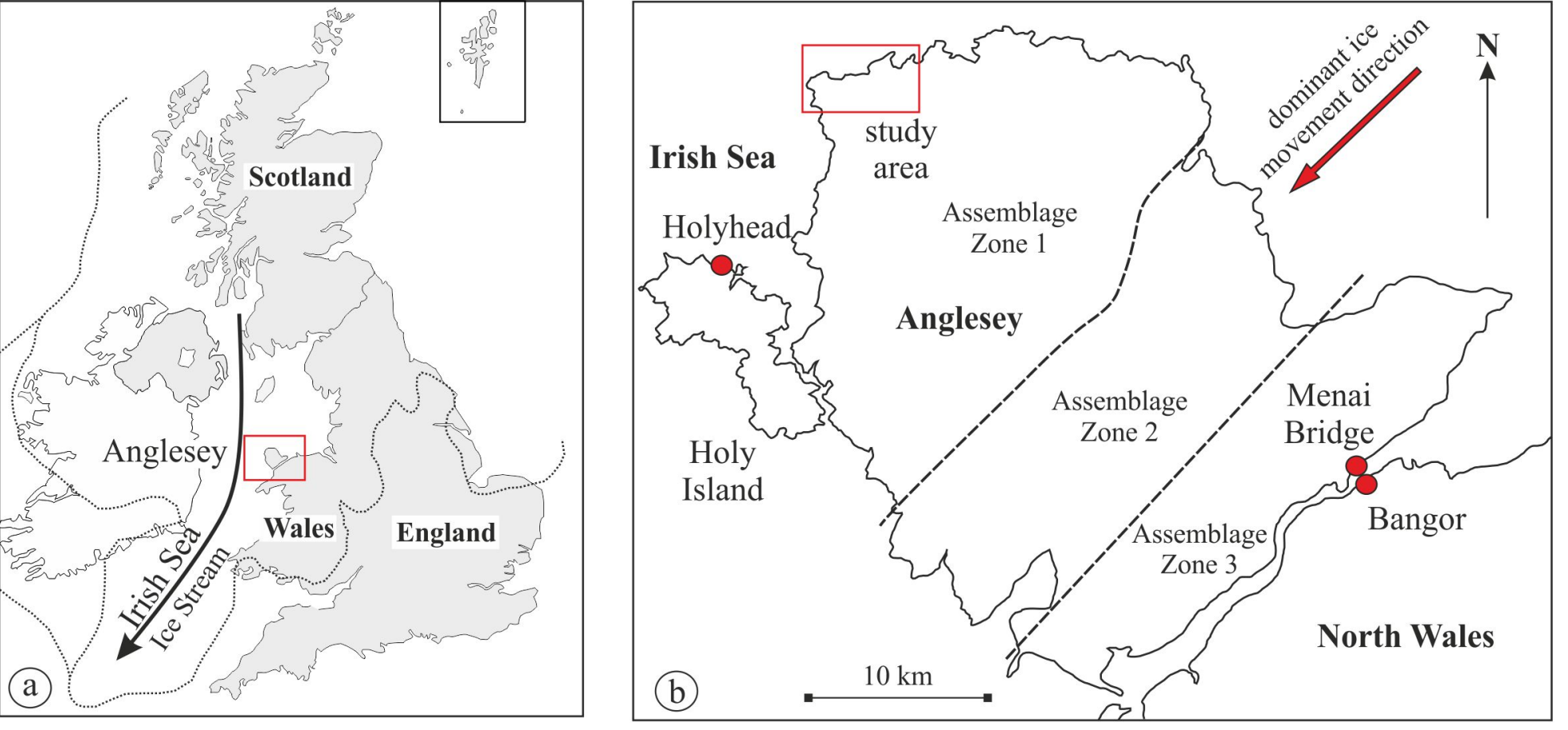

approximate limit of the British and Irish Ice Sheet

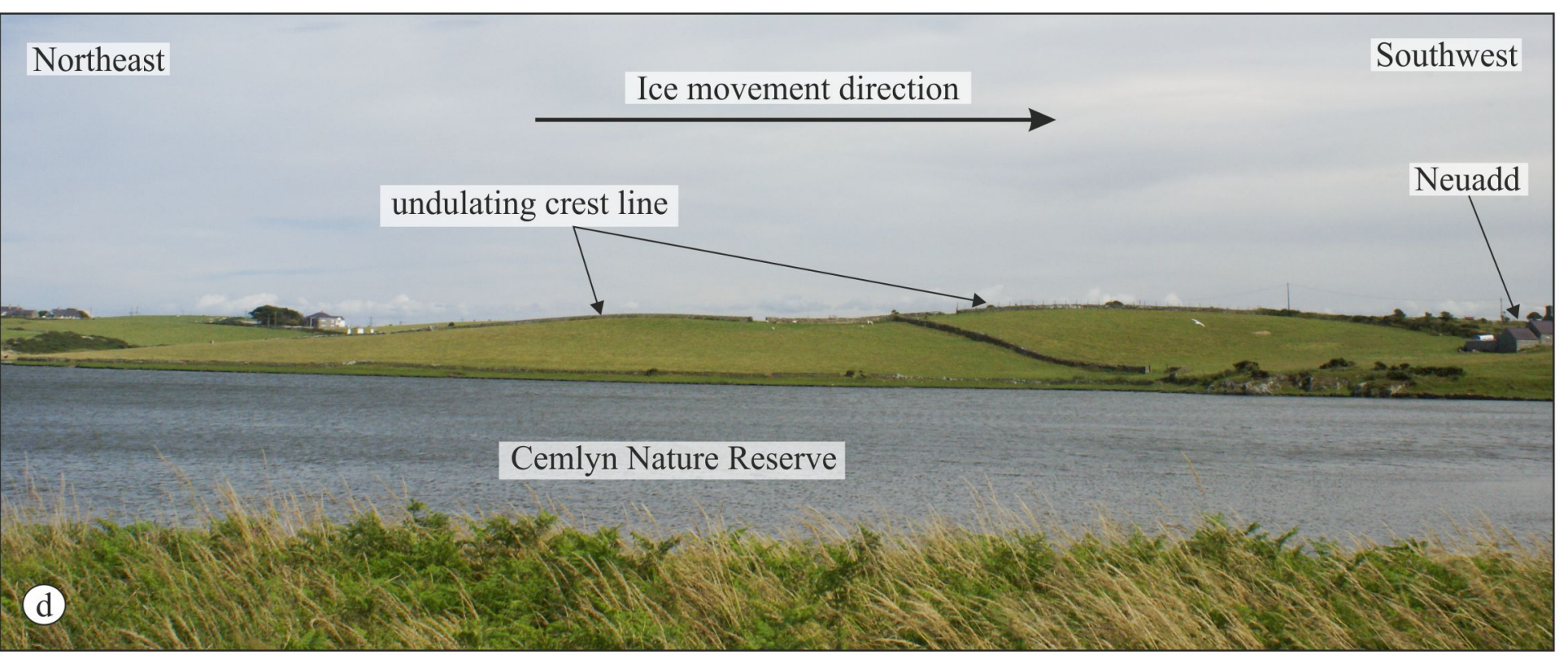

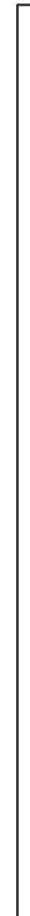

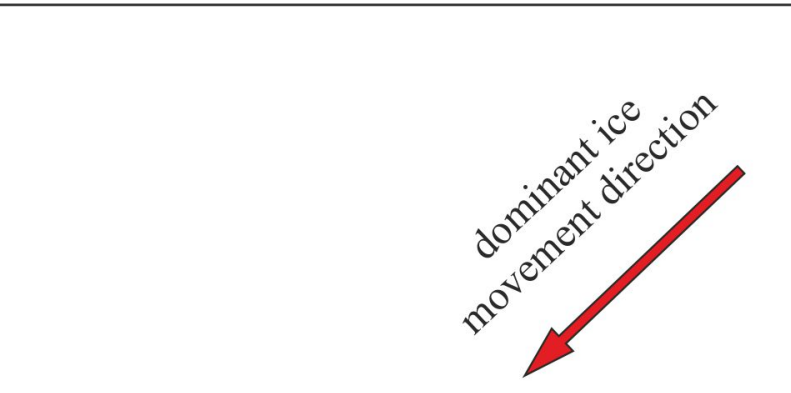

Cemlyn Bay
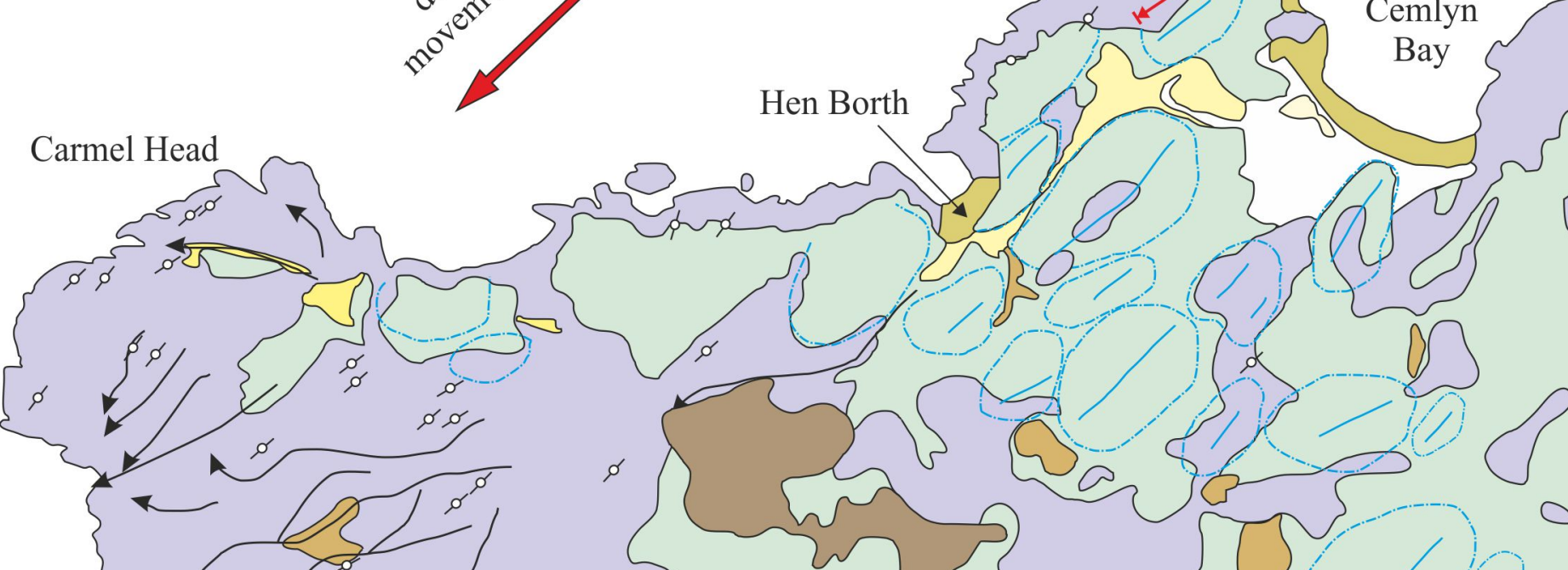

(c)

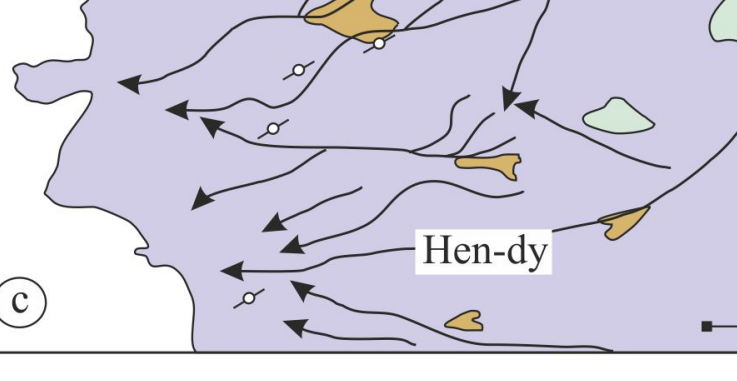

$\square$ beach deposits
$\square$ intertidal deposits
$\square$ alluvium
$\square$ peat $1 \mathrm{~km}$

$\square$ sand and gravel (glacial)

$\square$ diamicton (glacial)

$\square$ bedrock at or near surface

meltwater channel cut into bedrock

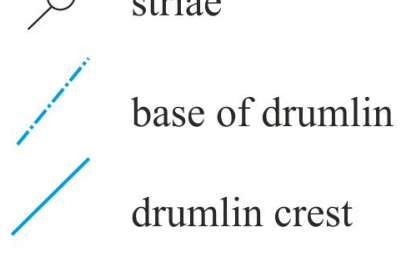

Northeast upper sandy diamicton Ice movement direction

stratification within diamictons

Southwest Irish Sea Till
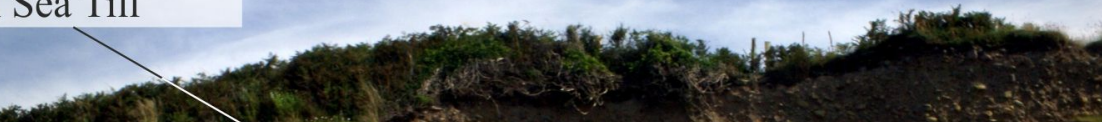
Nit.

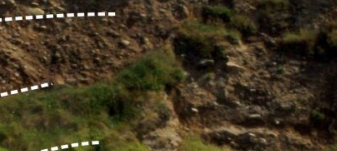


upper brown, sandy diamicton

Northeast (Irish Sea Till)

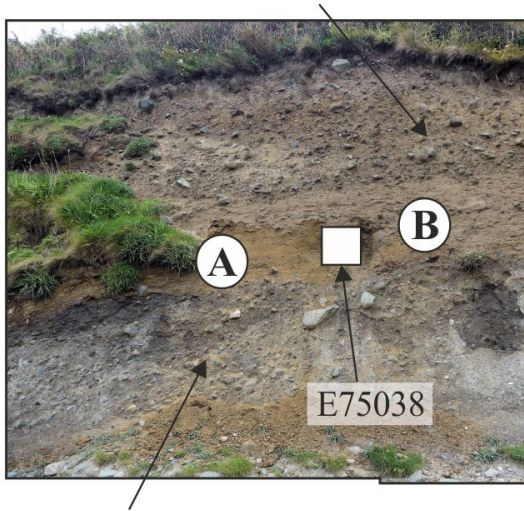

lower grey, locally derived diamicton laminated sand, silt and clay filling prominent hydrofracture small, steeply inclined, south-dipping hydrofractures led hudrofractures dip gently towards the south

\section{Northeast}

thin 'veins' of cemented sand and silt developed along

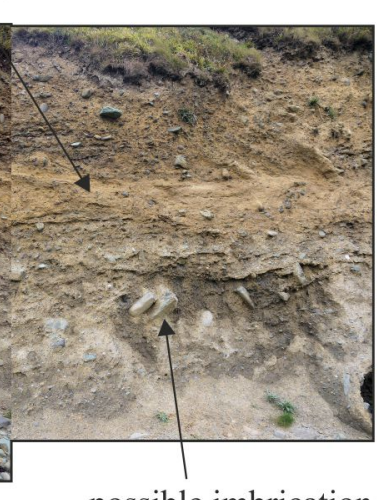

possible imbrication of large clasts

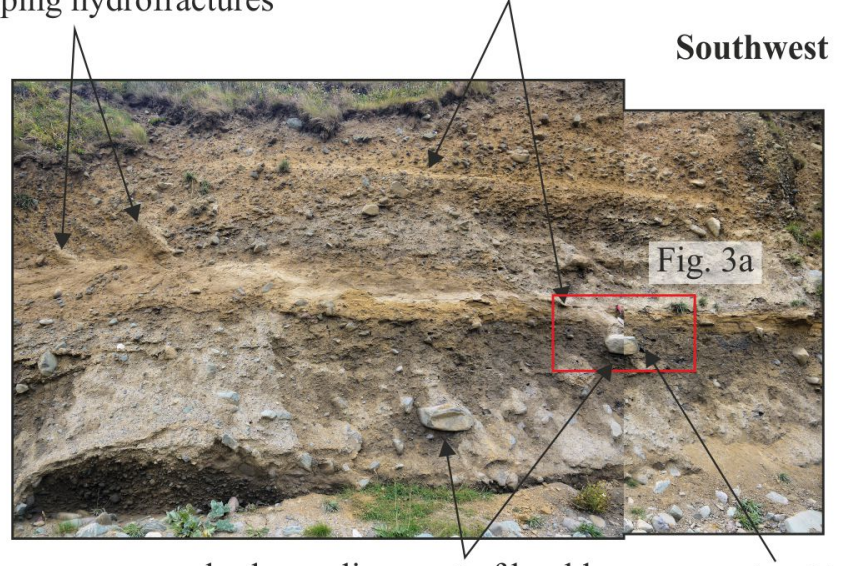

crude shape alignment of boulders parallel to stratification in diamictons striated boulder

Southwest

fractures/stratifiaction

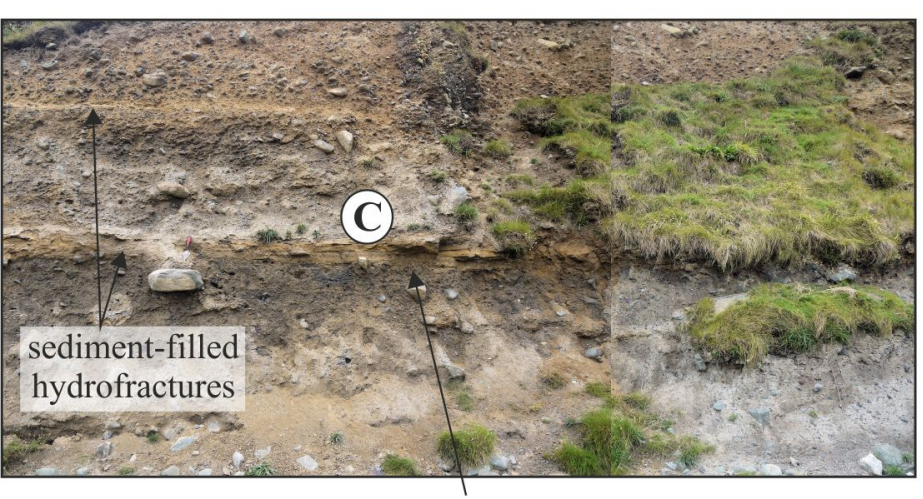

finely bedded/laminated sand, Northeast silt and clay filling hydrofracture large boulder 'wrapped' sediment-filled by sediment-filled hydrofracture hydrofracture

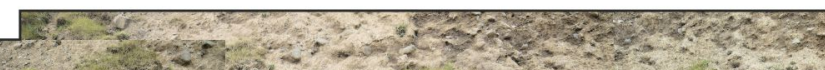

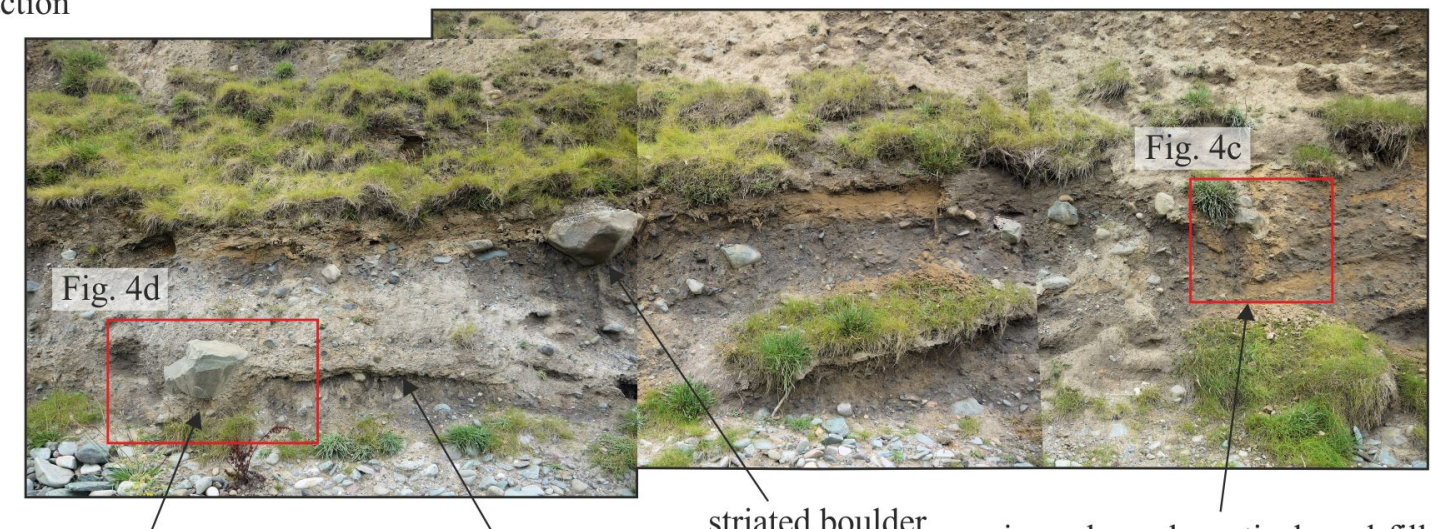

striated boulder linking two gently dipping hydrofractures

Southwest

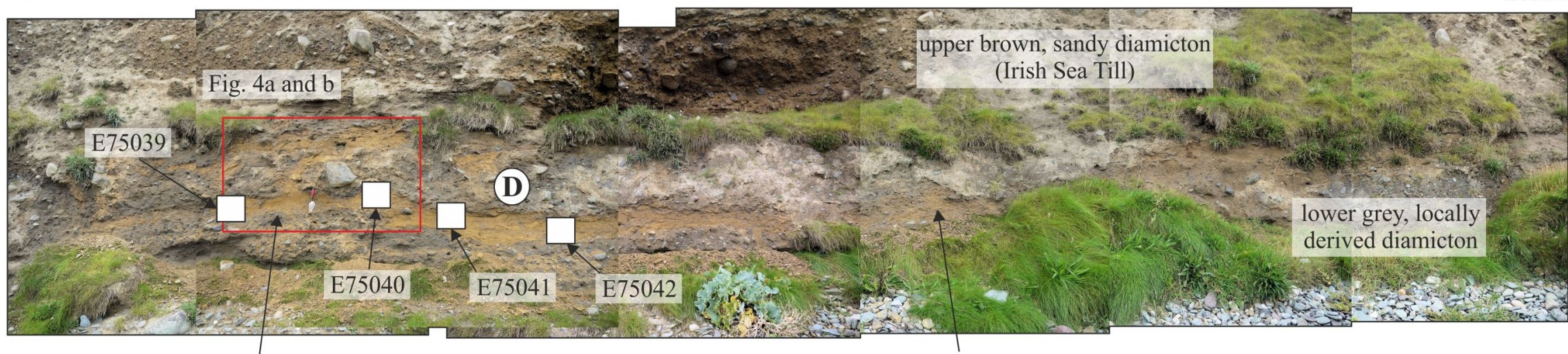

irregular, sub-vertical sand-filled vein linking two gently dipping hydrofractures

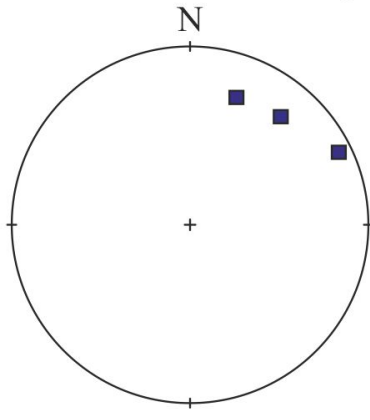

margin of hydrofracture (locations A and B)

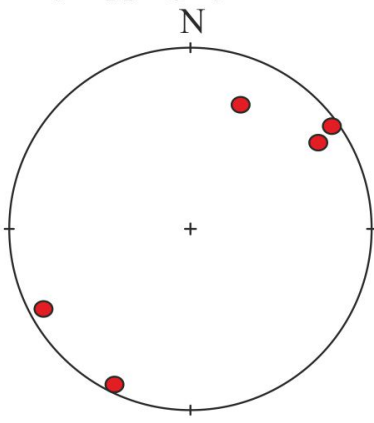

bedding in hydrofracture (location A)

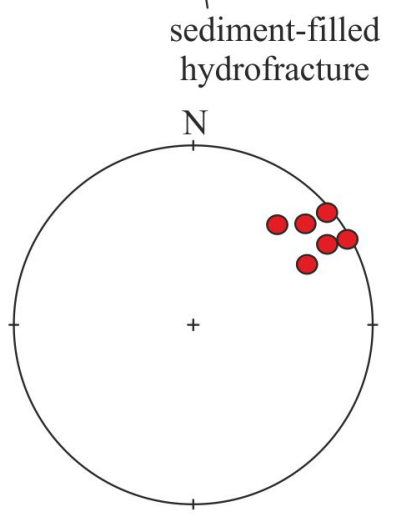

bedding in hydrofracture (location C)

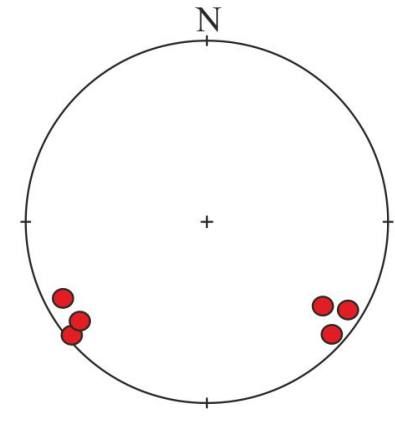

bedding in hydrofracture (location D)

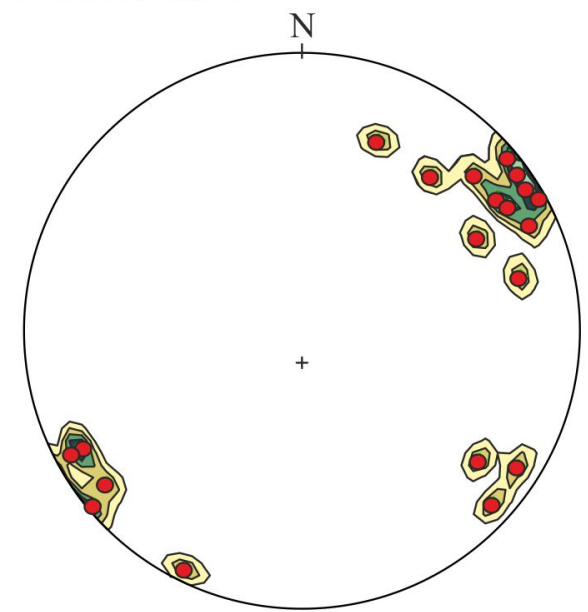

bedding in hydrofracture (location B) 

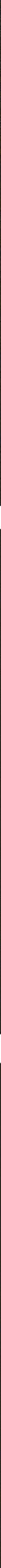


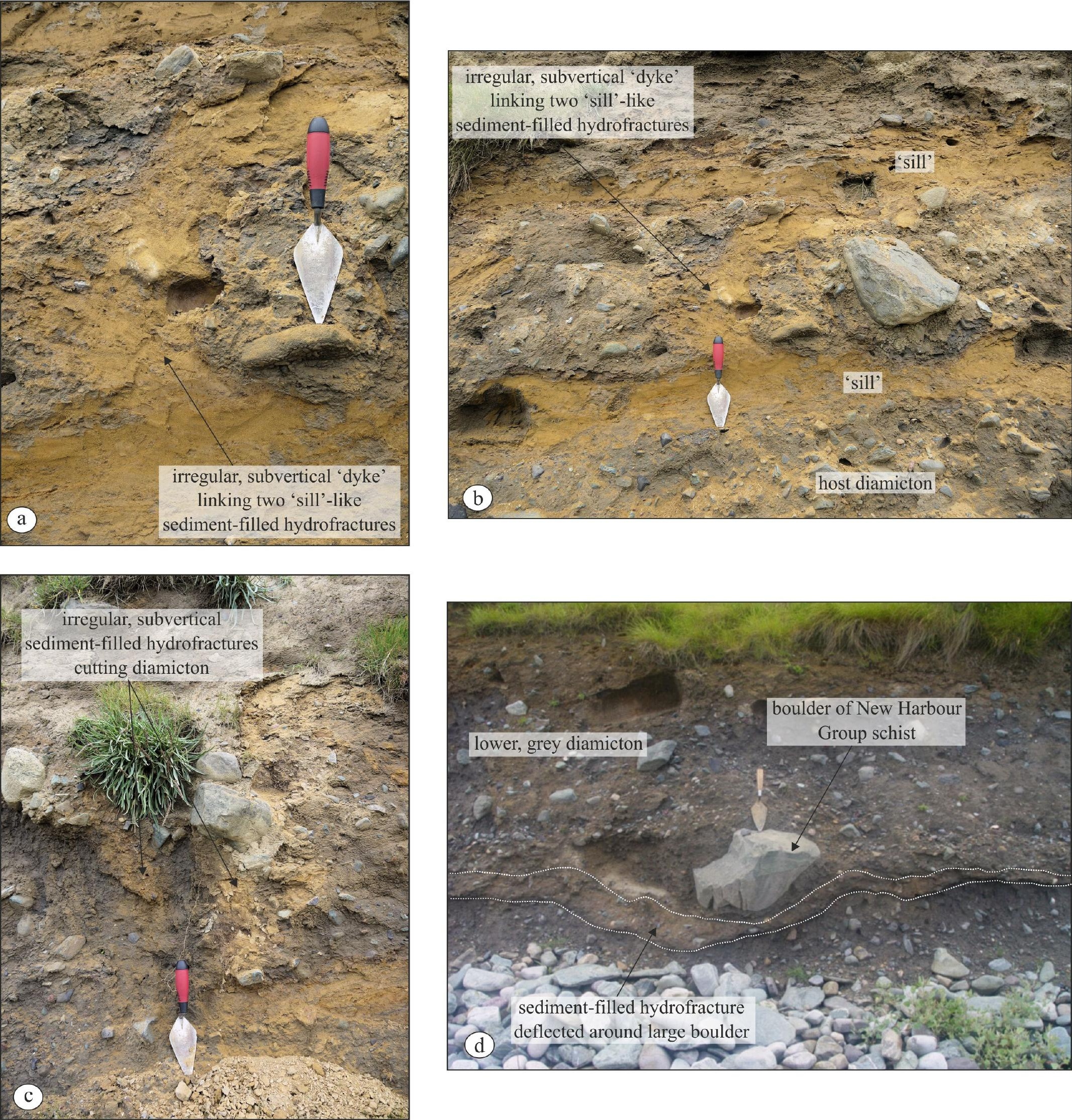




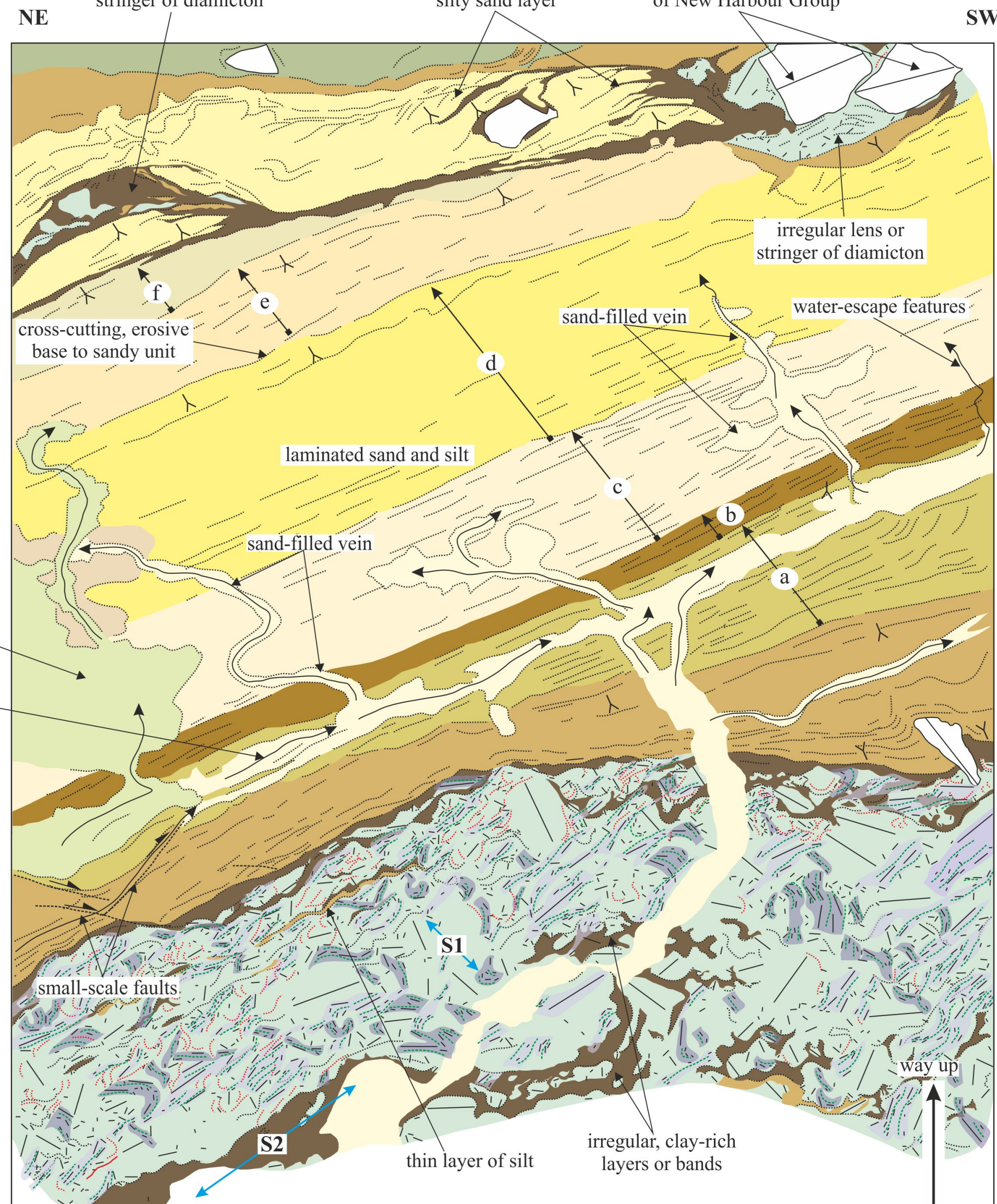

Cemlyn sample 1 (E75038) $10 \mathrm{~mm}$

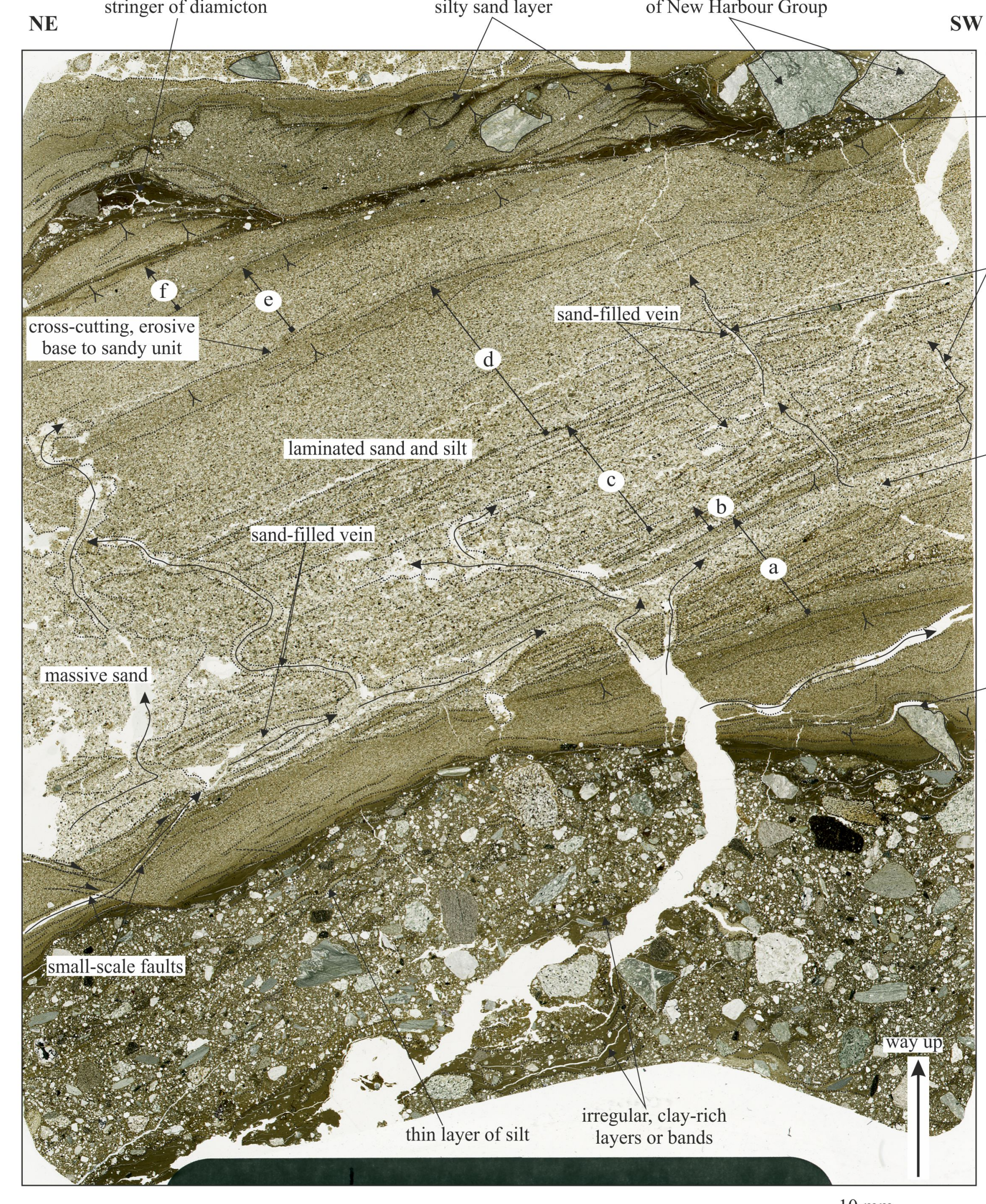

Cemlyn sample 1 (E75038) irregular lens or

water-escape features

laminated sand and silt filling hydrofracture system

sand-filled vein
parallel to bedding

wrapping of lamination angular to subangular, locally
derived lithic clasts in a fine, silty sand matrix
$\square$ diamicton
$\square$ S2 microfabric domains
- sense of movement on faults
$\uparrow$ graded bedding clast microfabric
$\square \square \square$ sand and silty sand filling cross-cutting veins $\quad \square \quad \square \square \square \square \square \square \square$ laminated sand, silty sand and silt layers filling hydrofracture $\quad \square$ arcuate and linear grain alignments 


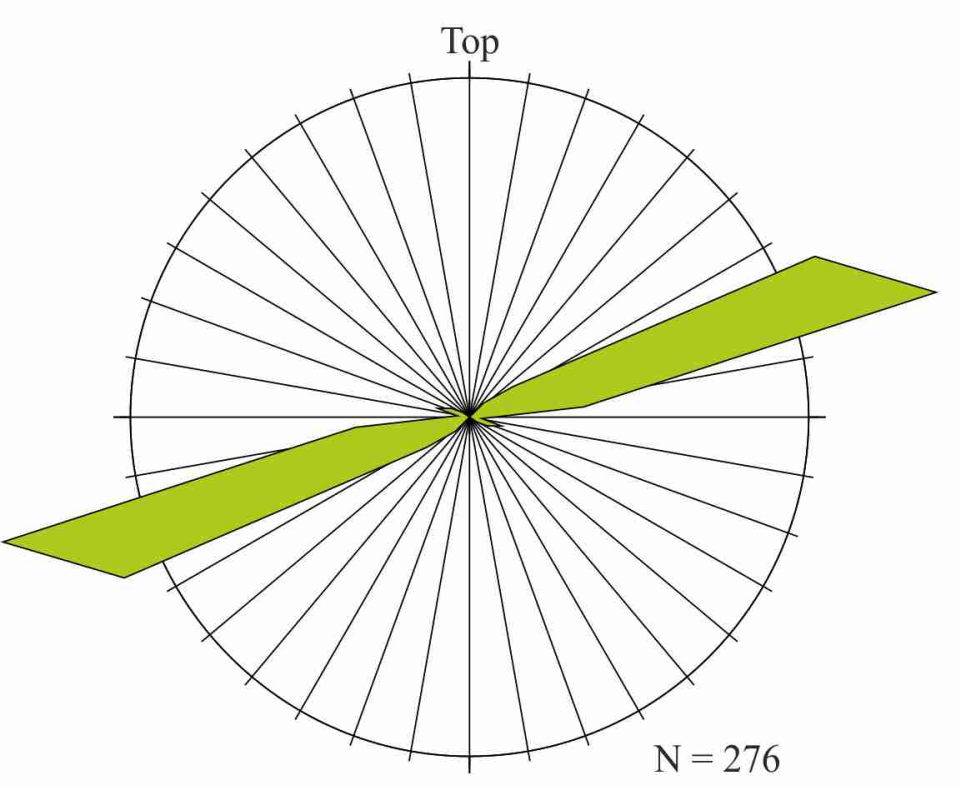

faults and shears
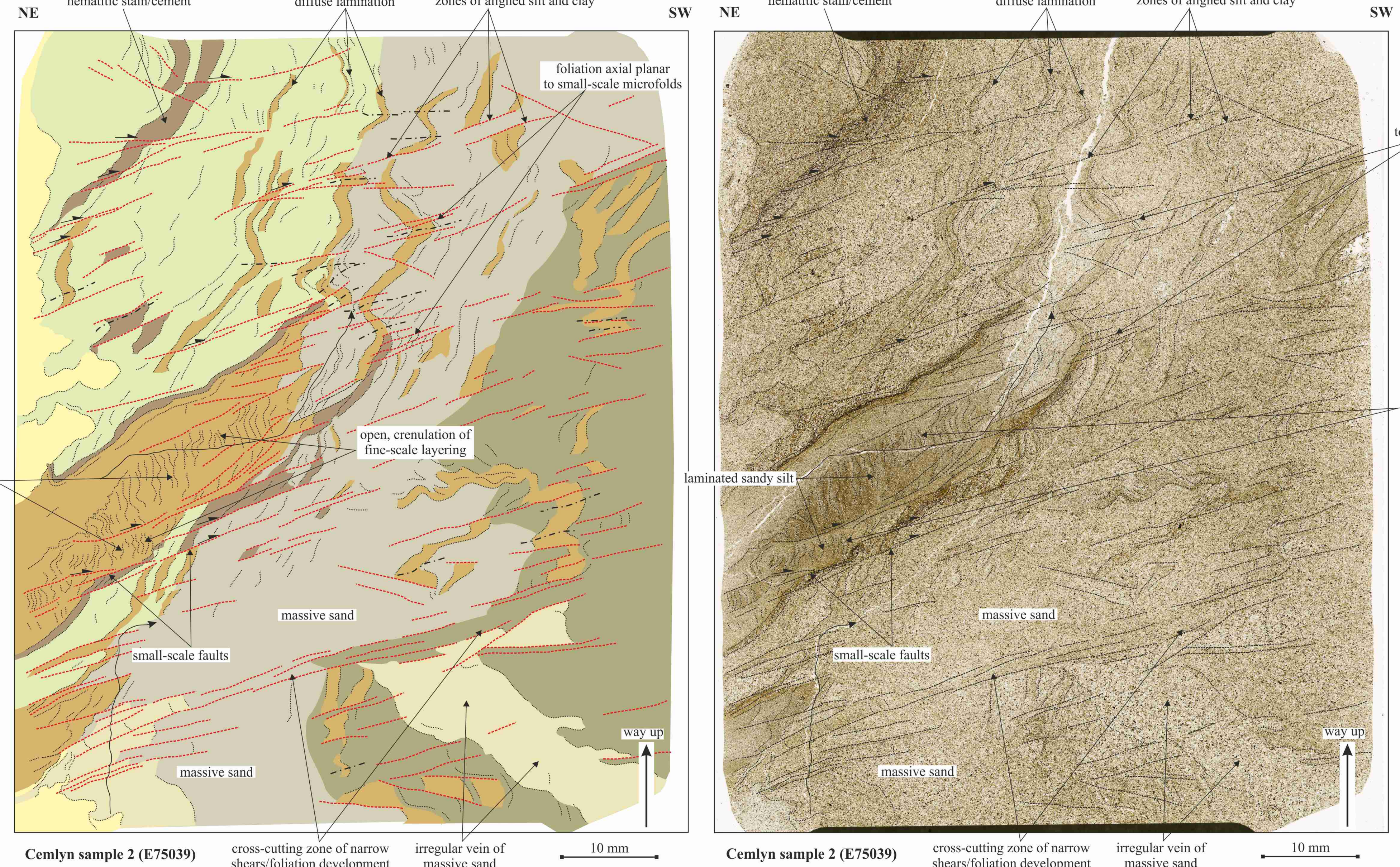

foliation axial planar
to small-scale microfolds

open, crenulation of
fine-scale layering $\begin{array}{ll}\text { cross-cilfoliation development } & \begin{array}{c}\text { irregular vein of } \\ \text { massive sand }\end{array}\end{array}$

$\square \square \square$ weakly laminated to massive sand and silty sand $\square$ clayey sand and sand with hematitic stain $\square$ silt sand silty sand layers $\square \quad \square$ homogenised matrix-poor sand 


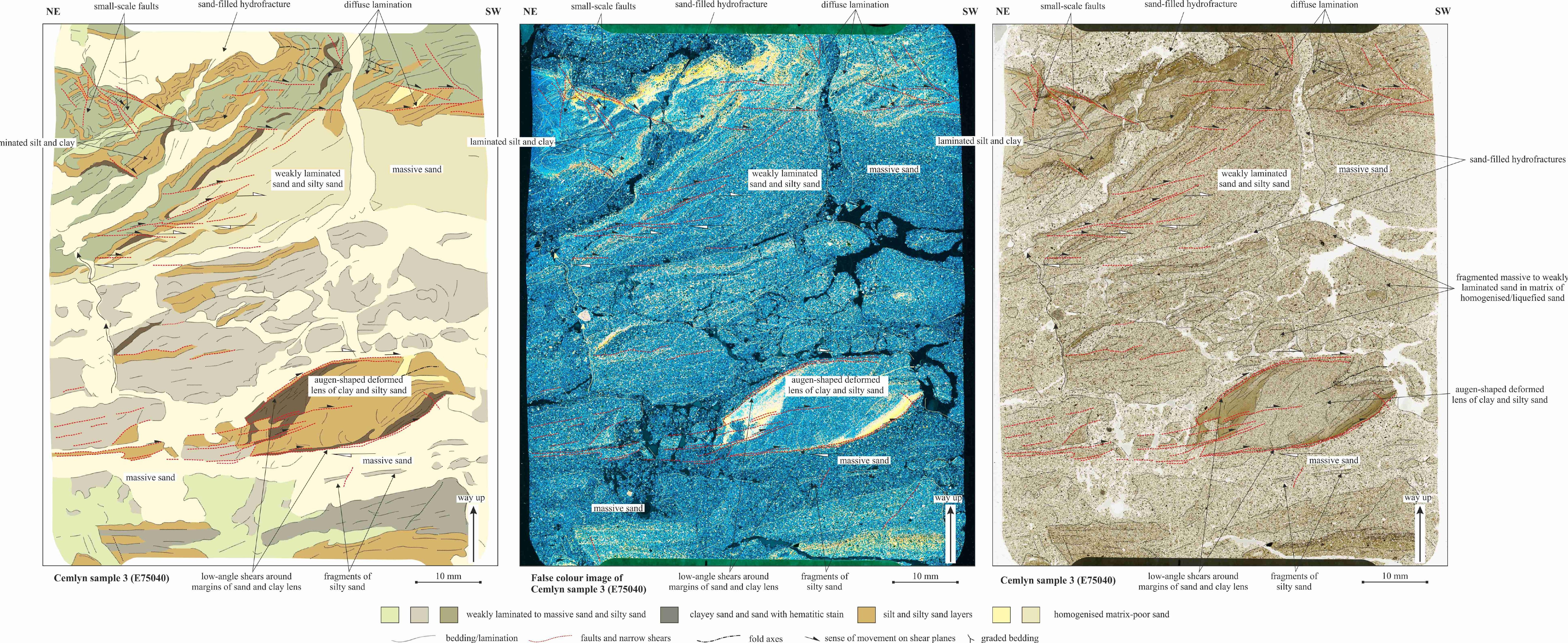


(a)

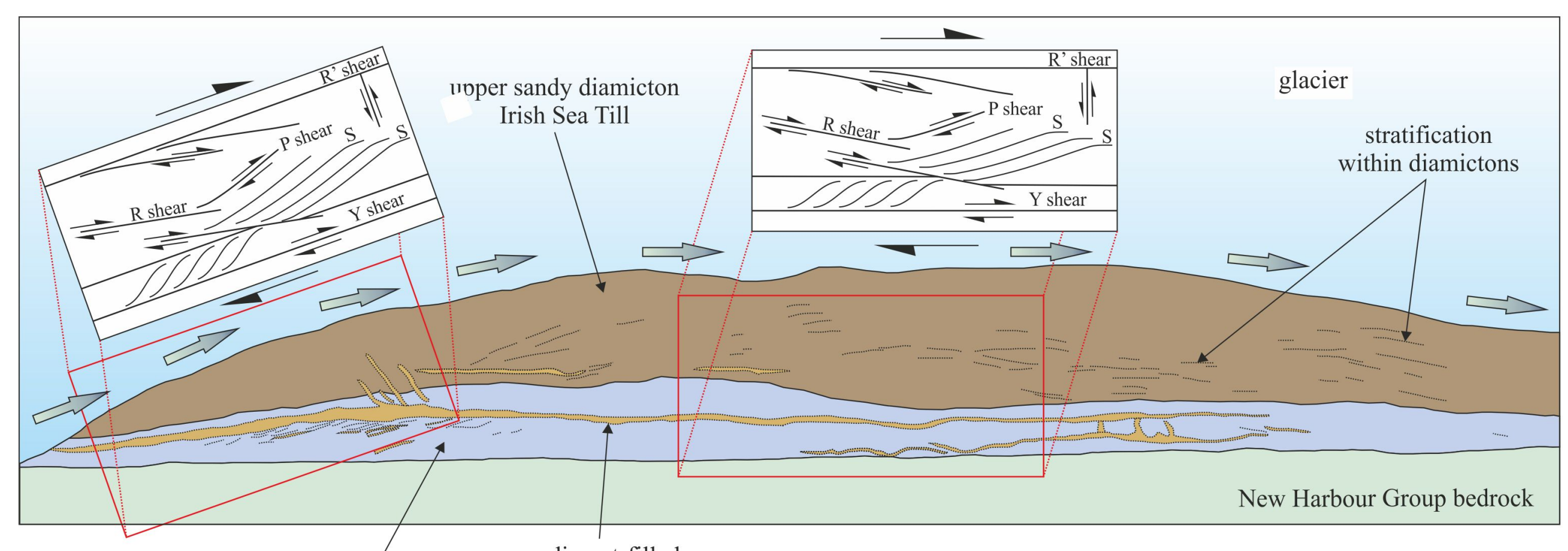

$4 \mathrm{~m} \quad \begin{gathered}\text { lower, locally } \\ \text { derived diamicton }\end{gathered} \quad \begin{gathered}\text { sediment-filled } \\ \text { hydrofracture system }\end{gathered}$

(b)

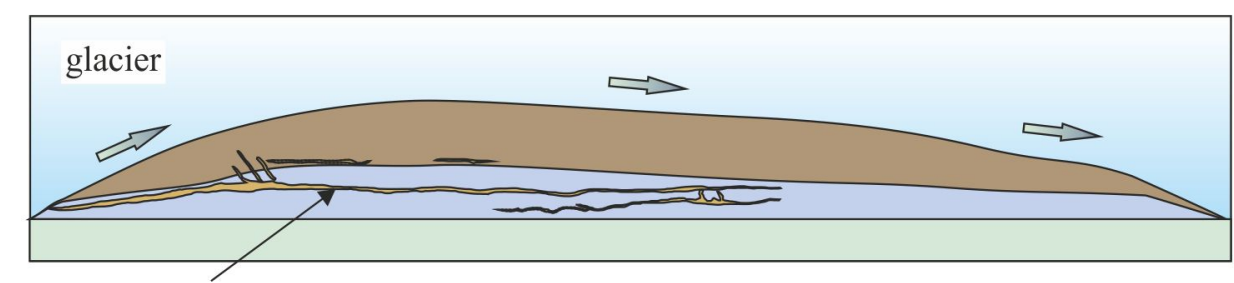

sediment-filled hydrofracture system

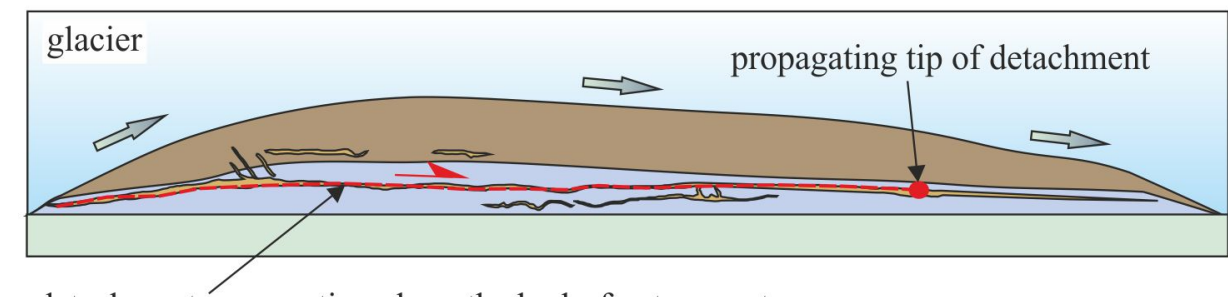

detachment propagating along the hydrofracture system
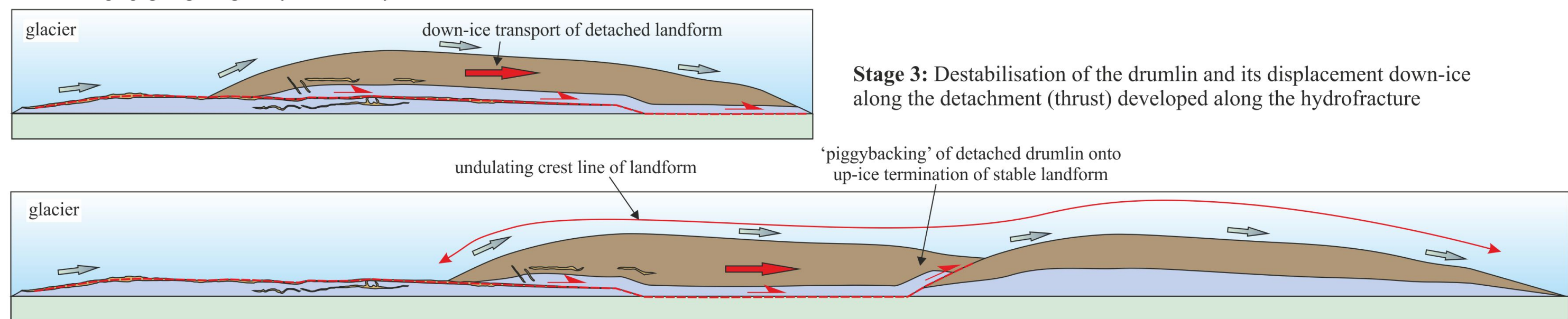

Stage 2: Continued down-ice development of the hydrofracture system followed by initial ductile shearing and propagation of a detachment (thrust) along the recently formed

hydrofracture. The sediment-filled hydrofracture represents a plane or weakness within the overconsolidated sequence of diamictons

Stage 1: Development of a hydrofracture system due to the penetration of overpressurised meltwater into the lower part of the drumlin

Stage 3: Destabilisation of the drumlin and its displacement down-ice along the detachment (thrust) developed along the hydrofracture

'piggybacking' of detached drumlin onto upper sandy diamicton (Irish Sea Till)

lower grey diamicton

sediment-filled hydrofracture system

New Harbour Group bedrock
Stage 4: Transportation/displacement of detached drumlin which is then 'piggybacked' onto the next down-ice landform resulting in the development of complex landforms with undulating crest lines (see Fig. 1d)

_..- detachment (thrust) $\rightarrow$ sense of displacement

sense of movement of detached drumlin

$\square$ sense of movement of overriding ice 